\title{
أساليب المعاملة الوالدية كما يدركها الأبناء وعلاقتها بانفعال الغضب لدى طلاب المرحلة الثانوية بمحافظة الليث
}

\author{
عزيز بن صالح بن عزيز البيجاني \\ تخصص التوجيه والإرثاد النفسي
}

هدفت الدراسة إلى الكثف عن مستوى أساليب المعاملة الوالدية المدركة لدى طلاب المرحلة

الثانوية بدحافظة الليث، والتعرف على العلاقة بين أساليب المعاملة الوالدية المدركة وانفعال الغضب لدى الدى

طلاب المرحلة الثانوية بدحافظة اللبث؛ ولتحقيق أهداف الدراسة، استخدم الباحث الهنهج الوصفي

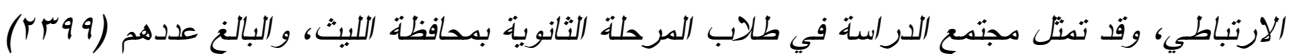

طالبًا، وتم اثتقاق عينة عشوائية بلغت (.0.) طالبًا، طبق عليها مقياس أساليب المعاملة الوالدية (إعداد:

الزبيدي ما • r)، ومقياس الغضب (إعداد: الثناوي والدماطي بو9 1))، وتوصلت الدراسة إلى أن أساليب

الدعاملة الوالدية من حبث مستوى إدراكها من قبل الأبناء جاءت في صورة الأب على النحو التالي:

(الثقبل- المساواة- الرعاية- الديمقراطية- التسامح)، وفي صورة الأم (الثقبل- الرعاية - المساواة -

الدبيقراطبة - التسامح)، وإلى وجود علاقة ارتباطبة عكسية (سالبة) ذات دلالة إحصائية عند مستوى

الدعنوية (1 . . ) بين الدرجة الكلية لمقياس أساليب المعاملة الوالدية (صورة الأب، صورة الأم)، وبين

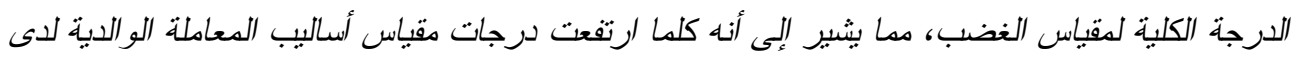

الطلاب، انخفض مستوى الغضب لليهم.

الكلمات المفتاحية: أساليب المعاملة الوالدية، انفعال الغضب، المرحلة الثانوية.

\section{Abstract:}

This study set out to investigate the extent of parenting styles as perceived by secondary school students in Al-Lith Governorate, and to examine the relationship between perceived parenting styles and anger emotion among secondary school students in Al-Lith Governorate. In order to achieve these aims, the descriptive correlational approach was employed. The population of the study included all secondary school students in Al-Lith Governorate amounting 2399 students, from which a random sample consisting of 350 students was selected to participate in the study. Data collection was carried out by means of a parenting styles scale (developed by: Al-zubeady, 2015), and an anger scale (developed by: AlShennawy and AL-Damaty, 1993). The results revealed that the levels of parenting styles perceived by sons for their fathers were in the following ranking (acceptance, equality, care, democracy, tolerance), and for their mothers were in the following ranking (acceptance, care, equality, democracy, tolerance). 
Moreover, a statistically significant negative correlation at the level 0.01 of significance was found between the overall score of parenting styles scale (perception of the father and perception of the mother) and the overall score of anger scale, which indicates the higher the scores of the parenting styles among students, the lower their anger levels were.

Keywords: Parenting styles- Anger emotion- Secondary school.

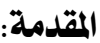

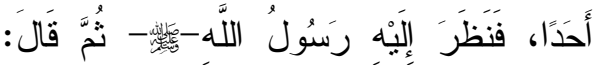

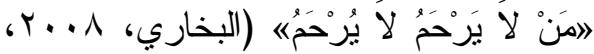

$$
\begin{aligned}
& .(0.1 \\
& \text { وفي هذا السياق، تعد التربية الحسنة } \\
& \text { للطفل هي أساس النمو السوي له، حتى و إن لنال } \\
& \text { تتوعت أساليب التربية، مما يجعل العلاقة } \\
& \text { قوية متينة بينه وبين والديه، ليتحقق الأمان }
\end{aligned}
$$

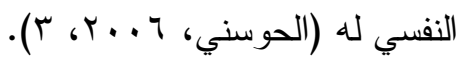

$$
\begin{aligned}
& \text { وتؤكد دراسة عباس (0. . ب) أن } \\
& \text { الأساليب السيئة من قبل الوالدين تؤثر على } \\
& \text { شخصية الأبناء وصحتهم النفسية، مما ينتج } \\
& \text { عن ذلك حدوث بعض المشاكل؛ كالغياب، } \\
& \text { و التسرب من المدرسة، و التدخين، وتعاطي } \\
& \text { المخدر ات، و العدوان، و الجر ائُ؛ نتيجة سوء }
\end{aligned}
$$

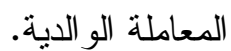

$$
\begin{aligned}
& \text { اهتم الدين الإسلامي بتربية الأبناء، } \\
& \text { ورغَّب فيها، وحث عليها من خلال الآيات } \\
& \text { القر آنبة، والأحاديث النبوية؛ لما لها من الأثر هن }
\end{aligned}
$$

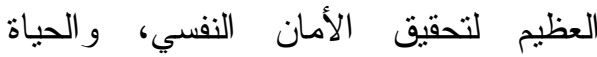$$
\text { المطمئنة للفرد، فقُرب الآباء من أبنائهج، }
$$$$
\text { و الإنصات إليهم، ومشاركتهم؛ وتوجيههم؛ }
$$

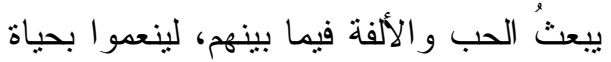$$
\text { طيبة رضية، ويتمنل ذلك في قول الله }
$$

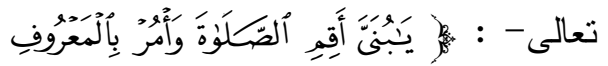

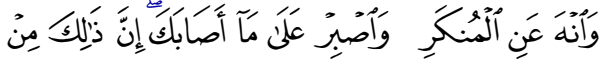

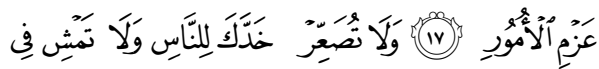

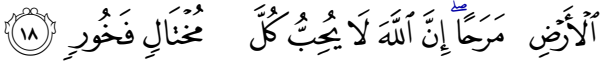

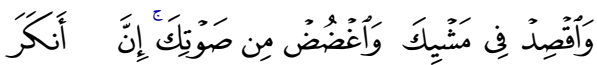

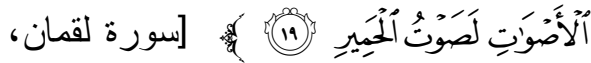

$$
\text { الآيات 19-1V] }
$$

وقد أنتتت نتائج در اسات متعددة؛ مثل

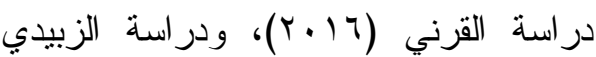

$$
\text { وكذلك في نهج المعلم الأول و القدوة، }
$$

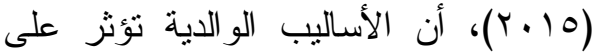

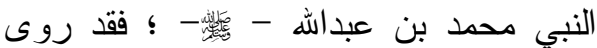
شخصية الأبناء، ونموهم الوجداني و السلوكي لوني لوني لوني

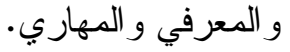

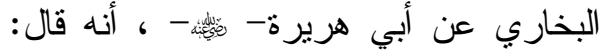

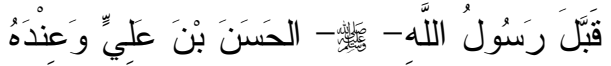

وتعد فترة المراهقة فترة تكوين

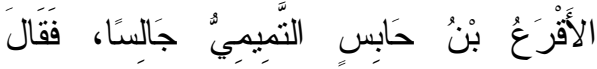

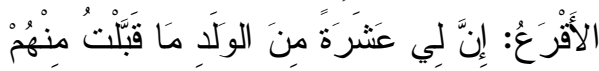




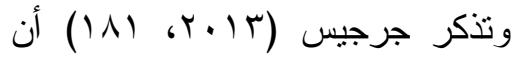

الغضب هو انفعال، والانفعال خبرة إنسانية

عامة، حيث تظهر من خلال مظاهر سلوكية

تعم آثار ها على الإنسان؛ جسمًا، ونفسًا، و إن هُن

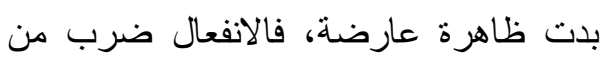

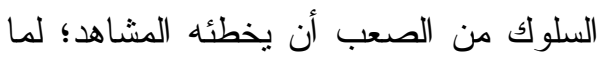
ينجم عنه من تغيير في ملامح الوجه،

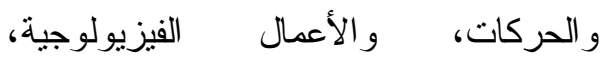

$$
\text { و التغييرات اللغوية. }
$$

ويعد الغضب من الأنماط الثنائعة لاى

المر اهقين، فيغضب المر اهق عندما يؤنب، أو يوبخ، أو ينتقد، أو يكرر له النه النصح

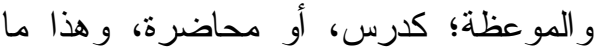

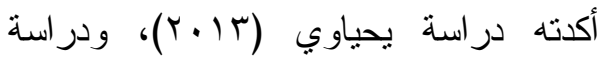

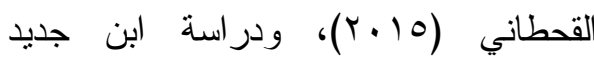
$\cdot(r \cdot 17)$

ويرى الباحث أن تلأك المعطيات المنمنلة في الآثار المترتبة و الناتجة عن

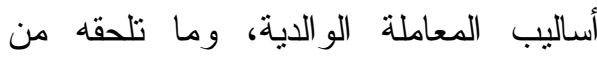

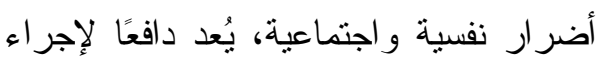
مزيد من البحوث؛ بهدف تحقيق مجتمع حيوي، يسوده الأمن النفسي، وذللك نتيجة

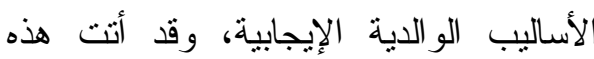

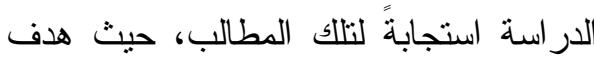
الباحث منها إلى المساهمة في خفض الغضب لدى الطلاب؛ لما له من آثار سلبية

$$
\text { على الفرد و المجتمع. }
$$

سليمة وصحيحة؛ لكي تعبر شاطئ الأمان،

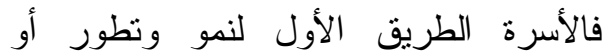
تدهور العلاقات الاجتماعية، التي ترنسم في حياة الطفل؛ فهي القوة و الدعامة الأساسية الفعالة في تكوين شخصيته، ففي بعض

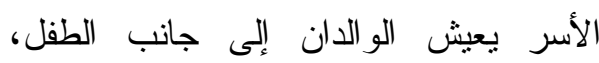
ولكنهما لا يستطيعان تقديم الأمان و الدعم النفسي المهيئ، لبناء شخصية اجتماعية فعالة

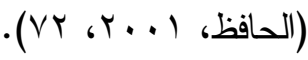
ومن ثم فإن أساليب المعاملة الو الدية قد تكون سببًا في الضغوط الإضافية على لقي الأبناء في مرحلة المراهقة، و التي تنزامن مع المرحلتين المتوسطة و الثانوية في التعليم العام، وما يتعرض لله المر اهق من ضغوط أخرى؛ حيث يسعى إلى البعد و التخلص من لهن مرحلة الطفولة، عن طريق التمرد الوجداني،

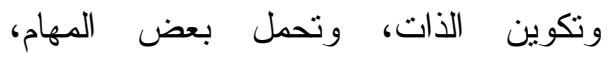
و المسؤوليات، و الوظائف التي يقوم بـنها،

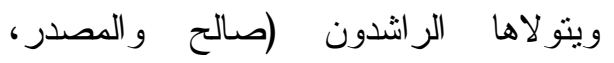

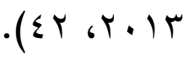
ونتيجةً لتأثير الأساليب الوالدية على

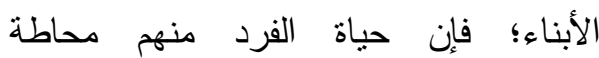
بالخبرات، و المو اقف، و والأحداث المختلفة،

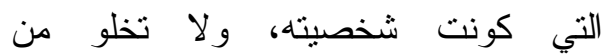
الانفعالات الطبيعية وغير الطبيعية، و التي تدفع الفرد نحو النمو السليم، والإيجابية، أو عدم التكيف، و السلبية مع ذاته ومجتمعه. 
المنتن في أساليب المعاملة الوالدية كما يدركها الأبناء وعلاقتها بانفعال

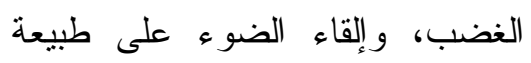

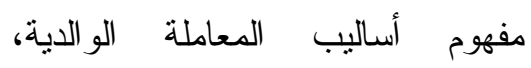

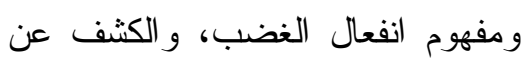

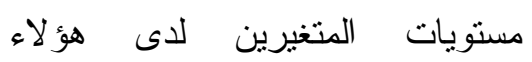
الطلاب، و العلاقة المحتملة بينهما. - الأهمية التطبيقية: جاءت أهمية هذه

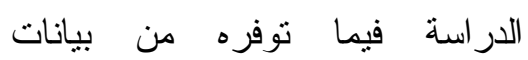
ومعلومات للجهات ذات العلاقة، ومنها هن الإدارة العامة للتوجيه و الإرشاد في وزارة التعليم، وقسم التوجيه و الإرشاد

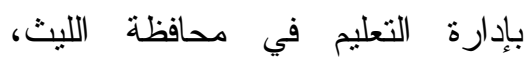
ومر اكز الرعاية الاجتماعية في وزارة العمل و التنمية الاجتماعية، و وأولياء أمور الطلاب.

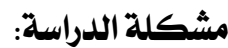

تحددت مشكلتها فـي الكـشف عـن

طبيعة العلاقة بين أساليب المعاملة الو الدية-

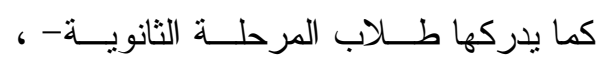
و انفعال الغضب، ولمعالجة هــــه المـشكلة ئهل

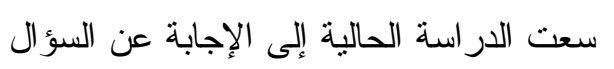
الرئيس التالي: - هل هناك علاقة ارتباطية دالة إحسـصائيًا (الم $)$

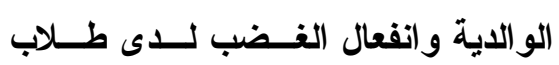
المرحلة الثانوية بمحافظة الليث؟

$$
\text { أهداف الدراسة: هدفت الدر اسة إلى: }
$$

1 - الكثف عن مستوى أساليب المعاملة

الو الدية المدركة لدى طلاب المرحلة الثانوية بمحافظة الليث.

r- الكثف عن مستوى انفعال الغضب

لاى طلاب المرحلة الثانوية بمحافظة

$$
\text { الليث. }
$$

r- التعرف على العلاقة بين أساليب

المعاملة الوالدية المدركة ول وانفعال

الغضب لدى طلاب الرحلة الثانوية

$$
\text { بمحافظة الليث. }
$$

ـ- التعرف على الفروق في أساليب

المعاملة الو الدية المدركة لدى طلاب

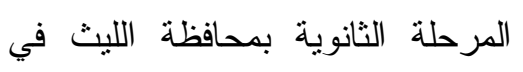

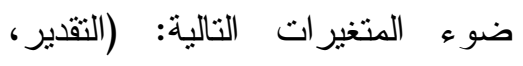

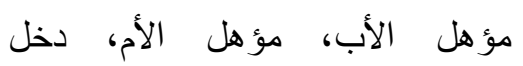

$$
\text { (الأسرة). - مؤهن }
$$

0ـ التعرف على الفروق في انفعال

الغضب لاى طلاب المرحلة الثانوية

بمحافظة الليث في ضوء المتغيرات التالية: (التقدير، مؤهل الأب، مؤهل

$$
\text { الأم، دخل الأسرة). }
$$

أهمية الدراسة: تحددت أهية الدراسة فيما

- الأهمية النظرية: اكتسبت الدراسة الحالية أهميتها من خلال الموضوع 
يستخدمها الآباء و الأمهات مع أبنائهر أثناء تربيته في مختلف المو اقف الحياتية".

وقد تبنى الباحث تعريف الزبيدي

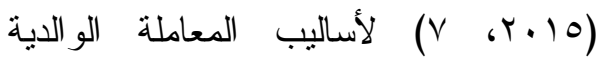

و التعريف الإجرائي هو عبارة عن الدرجة

الكلية للطالب على مقياس أساليب المعاملة

الو الدية المستخدم في هذه الدر اسة.

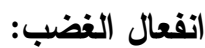

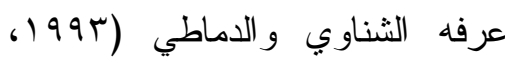

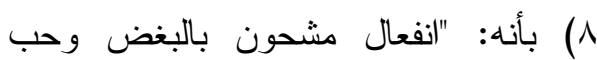
الانتقام و الر غبة في العدوان".

وقد اعتمد الباحث على تعريف لعثي

الثناوي و الدماطي (19991، ^) في بحثه

والتعريف الإجرائي هو عبارة عن الدرجة

التي يحصل عليها الطالب في مقياس انفعال

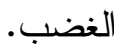

الإطار النظري والدراسات السابقة:

أولا: الإطار النظري: ويتكون من المباحث

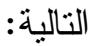

المبحث الأول: أساليب المعاملة الو الدية:

تعتبر أساليب المعاملة الوالدية هي الئل

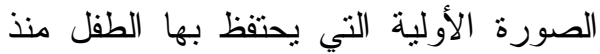

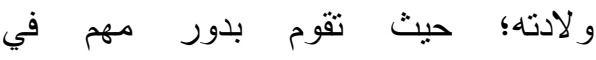

تتكيل هويته، وتكوين اتجاهاته، وميوله،

ورغباته، و ونظر اته للحياة، كما أن الو الدين ونكين

هما الأساس لبناء هذه الثخصية، وتو افقها،

ونموها، باتباع الأساليب المتزنة، وتنهيئة
وتفرع من هذا السؤال الأســـئلة الفرعيــة

الآتية:

1 - ـ ما مستوى أساليب المعاملة الو الديـــة

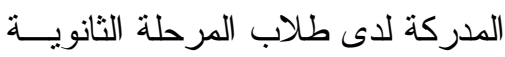

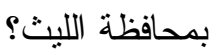

r- ـ ما مستوى انفعال الغضب لدى طلاب

المرحلة الثانوية بمحافظة الليث؟

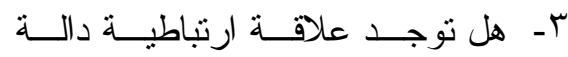

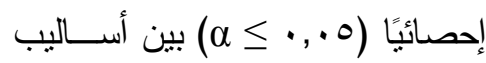

المعاملة الو الدية المدركـــة و انفعــال الهـال

الغضب لدى طلاب المرحلة الثانويـــة

بمحافظة الليث؟

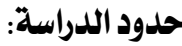

- الحدود الموضوعية: أساليب المعاملـــة

الو الدية و علاقتها بانفعال الغضب لـــى

طلاب المرحلة الثانوية بمحافظة الليث.

- الحدود البشرية: طلاب المرحلة الثانوية

(بنين) بمحافظة الليث.

- العدود المكاتيــة: المــــارس الثنانويــة

(بنين) بمحافظة الليث.

- الحدود الزمانية: الفصل الدراسي الثاني

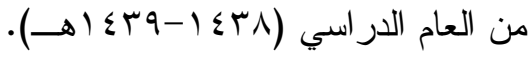

مصطلحات الدراسة:

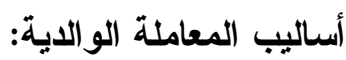

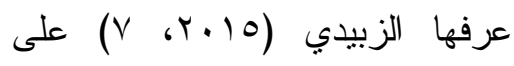

أنها: "مجموعة التفاعلات السلوكية التي لتربي 
واجتماعية دقيقة، لها علاقة بحياة الفرد، وتؤثز فيه منذ الأشهر الأولى من ولادته،

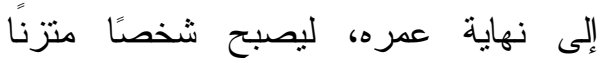

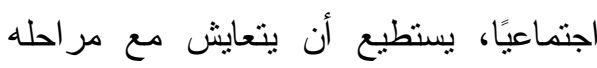
العمرية، فلا يمكن تجاوز ها في أية مرحلة

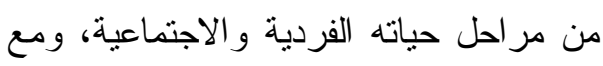
ذللك عليه أن يتأقلم ويتكيف لكل مرحلة منها، وبعد انتهاء الفترة الزمنية للمرحلة، عليه

تزكها، و اكتساب ظروفها وشروطها ذات المر احل المختلفة؛ شكلاً، ومضمونًا. كما أن ؤن عملية التكيف الاجتماعي تنتلب مقدرة ذكائية، وقابلية اكتسابية، ومرونة تفكيرية،

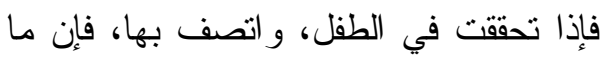
يكتسبه داخل محيط أسرته من خلا أساليب المعاملة الوالدية ستكون ميسرة وسهلة، أما إذا كانت قدر اته وقابليته متدنية، فإنه سيو اجه

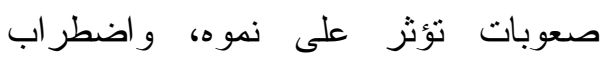

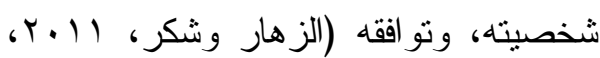
. (rar الاتجاهات النظرية لأساليب المعاملة

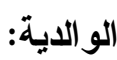
نظرية التحليل النفسي: تهدف نظرية التحليل النفـسي إلـى لـى العناية بشخصية الطفل، والارتقــاء بنـشـأة سماته، و اضطر اباته النفسية، فاهتمت بدر اسة ولة

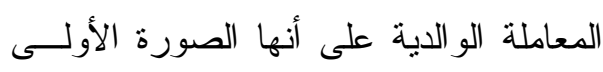

الجو العام المناسب للطفل منذ و لادته، وتقديم الرعاية، وكل ما يساعده للانتقال من مرحلة

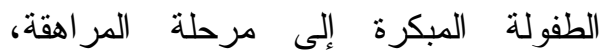

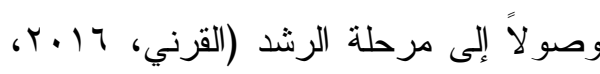
كما تعد أساليب المعاملة الوالدية من

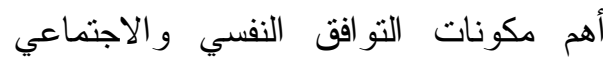
للطفل، فبقدر ما تكون أساليب المعاملة الوالدية سوية، يكون السو اء لشخصية الأبناء

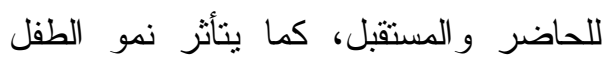
الانفعالي و العاطفي بناءً على أنماط التفاعل

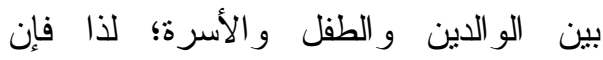
حساسية مرحلة الطفولة تتمنل بأنها مرحلة

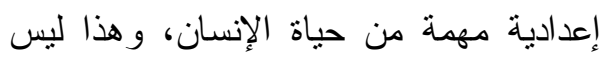

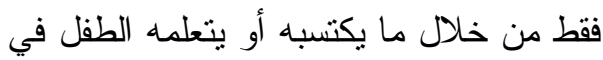

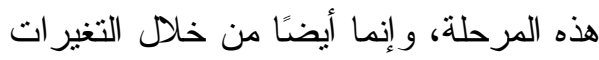
النمائية، و المعرفية،و الانفعالية، و الاجتماعية،

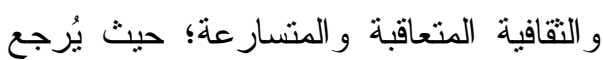
كثير من العلماء و العاملين في الحقل النفسي ولي جميع مشكلات الكبار التي تعتريهم إلى من لهين

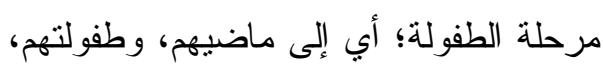
وتجاربهم السابقة، وخبر اتهم التي مروا بها،

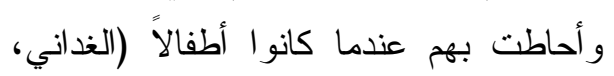
.$(106 r) \varepsilon$ أهمية در اسة أساليب المعاملة الو الدية:

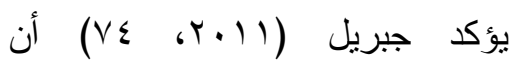
أساليب المعاملة الوالدية عملية نفسية 
المثالية، و التي تتأثر بقيم الو الدين، وأساليبهما

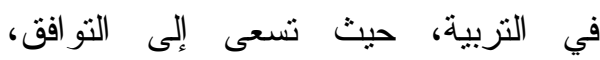

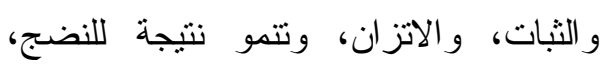

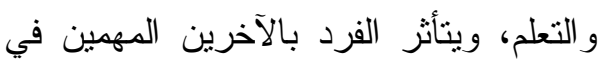

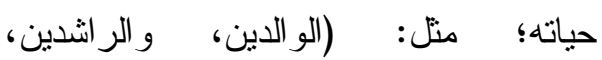

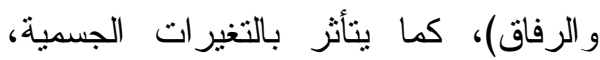

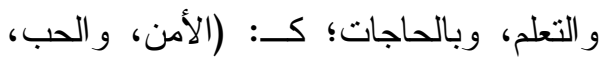

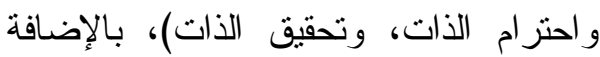

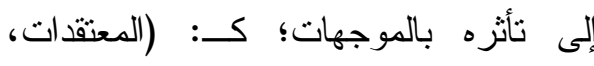

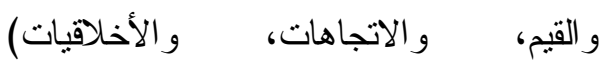
(j)

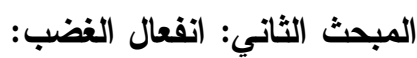
خلق الله الإنسان وزوده بانفعالات جسمية، تعينه على مختلف جو انب الحياة؛ فمنذ و لادته يُلاحَظ البكاء و الضحك أحيانًا،

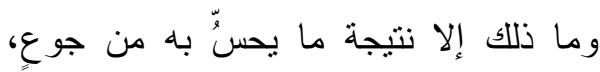

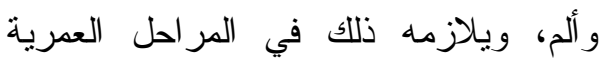

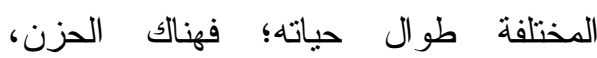
و الغضب، و الفر ح، و العدو ان، ولكنها تخضع

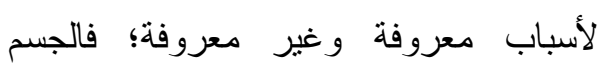
يحتاج للانفعالات، ولكن في الحدود الطبيعية

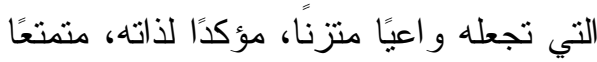
بصحة نفسية جيدة، بعيدًا عن تلك الانفعالات

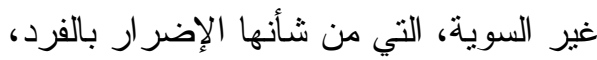

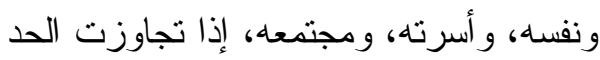

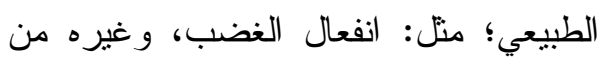

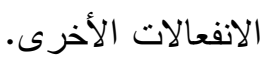

التي ترنسم في مخيلة الطفل، بوصفها المؤثر

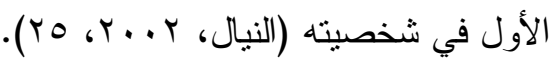

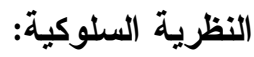
اهتمت هذه النظرية بالسلوك؛ فهي

ترى بأنه متعلم، وأن الفرد باستطاعته تعلم السلوك الصحيح وغير الصحيح، فيسنطيع بله بله تعلم السلوك المنو افق مع نفسها، وبيئنه،

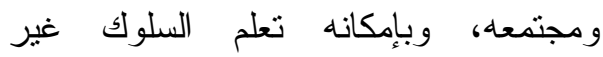
المتوافق، غير أن السلوك المتعلم يمكن وبامله تغييره، وتعديله، ومن أسماء هذه النظرية: نظرية المثير و الاستجابة، فكل سلوك لهنه له مثير ، وكلما كانت العلاقة بين ركني هذه النظرية - المثير و الاستجابة - منو افقة كان السلوك سويًا، أما إذا كانت العلاقة بينهما غير سليمة كان السلوك غير سوي، و الأمر

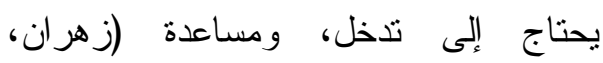

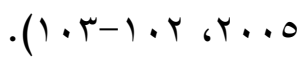
نظرية الذات: هدفت نظرية الذات- للعالم كارل روجرز Rogers Carl- إلى الاهتمام بالذات؛ فهي تمثل قلب نظرية روجرز من

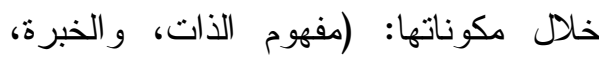
و الفرد، و السلوك، و المجال الظاهري)؛ حيث إنها كينونة الفرد، كما أنها تتمو وتتفصل ولهل تدريجيًا عن المجال الإدراكي، وتكون قوتها وتتكوينها من خلال التفاعل مع البيئة، وهي الإدري الذات المدركة، و الذات الاجتماعية، و الذات 
ويرى الباحث بعد استعر اض

التعاريف السابقة أن انفعال الغضب ردة فعل

لبعض الاستثار ات التي يمر بها الفرد، وينتج

عنها الهيجان، وبعض التغيرات النفسجسمية،

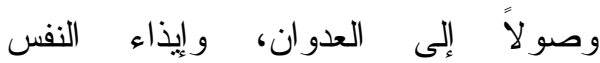
و الآخرين.

مكونات الغضب:

يتكون اتفعال الغضب من ثلاثة جواتب هي

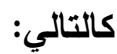

ا - جانب شعوري ذاتي، يعلمه الثخص

المنفعل وحده، ويختلف من انفعال إلى

آخر تبعًا لنوع الانفعال وهذا الثعور

بمكن دراسته عن طريق التأمل

$$
\text { الباطني. }
$$

r- جانب فسيولوجي داخلي كخفقان

القلب، وتغير ضغط الدم، و اضطر اب

التتفس، وسوء الهضم، و وازدياد إفر از

$$
\text { الغدد الصماء. }
$$

"- جانب خارجي ظاهر، يشتمل على

مختلف التعبير ات

و الأوضاع و الألفاظ والإيماءات التي

تبدو على الثخص المنفعل، و هذا هو

الجانب الذي نحكم منه على نوع

الانفعال عند الآخرين (عواد وسمور،

$$
\text { . ( ) } \leqslant 0, r . . \varepsilon
$$

تعريف انفعال الغضب: من أهم التعريفات التي تتاولت مفهوم انفعال الغضب؛ ما يلي: تعريف أفيريل (Averill, 1982, 6) بأنه: "انفعال شديد يشتمل على حالة من الصراع، ويرتبط في المستوى البيولوجي بأجهزة العدوان، كما برنبط بطاقات الحياة الاجتماعية المتعاونة، وبالتجسيد الرمزي، و الوعي بالذات، وفي المستوى النفسي فإنه يهدف إلى تصحيح بعض الجوانب التي يعدها الفرد الغاضب خاطئة من وجهة نظره، أما في المستوى الاجتماعي فإنه

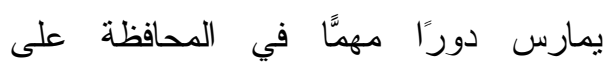
المعايير الخلقية المقبولة".

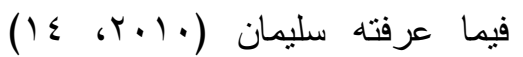

بأنه: "حالة انفعالية، نشمل مجموعة من الدرجات، تبدأ بالغضب البسيط؛ كالغضب، و الاستنارة، و الضيق، وتتتهي بالغضب الثديد، المتمنل في التمزيق، و التثمير، والعنف، كما يتسم سلوك الفرد بالهياج الثديد، و الصر اخ، و التذمر".

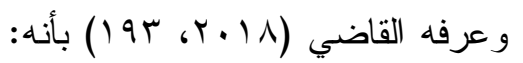
"انفعال نفسي يشعر به الإنسان نتيجة الإساءة إليه، أو لعدم تحقيق مطالبه، ورغباته، أو نتيجة لعرقلة تحقيقها، وتختلف صور التعبير عن الغضب باختلاف الأفراد، ومراحل حياتهم، و اختلاف بيئاتهم، وثقافاتهم". 
ويرى الباحث أن أسباب الغضب

ويؤدي الغضب إلى صراع ذي جانبين:

منتوعة؛ منها ما يكون من الفرد، أو ناتج

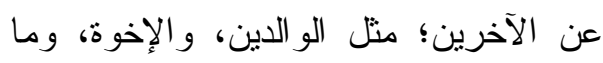
يحدث بينهم من شجار ، واختلاف، وكذلك الك الأصدقاء، وزملاء الدراسة، كما أن درجة الغضب تختلف من شخص لآخر. الآثار المترتبة على الغضب:

يعد انفعال الغضب حالة نفسية تذخل ضمن عملية الاستجابة و المثير ، وتختلف هذه الاستجابة من شخص لآخر، ويتفاوت سلوك عن آخر، ونفسية عن أخرى، ولكن ييقى الغضب حالة استتفار للنفس، قد تؤدي إلى ردود فعل يندم عليها الآخرون؛ وذلك لأن النفس تتحول عن طور ها الطبيعي إلى الهيجان، والانفعال، ومن ركودها إلى

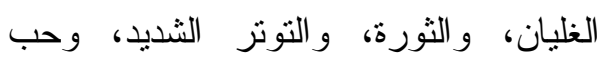

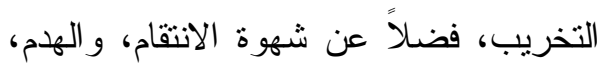
و الإعراض عن الوقار، والرزانة، و إلى سيكولوجية الاعتداء، و الضرب، وإطلاق التهديدات، وما إلى ذللك من الردود العقابية، ولكن هذه الثورة النفسية سرعان ما يخمد لهيبها، ويلحق الإنسان بعد ذلك ندم على ما فلى بدر منه في تلك الحالة، وهو فضل من الله على الناس أن جعلهم بهذه الصورة، بحيث لا لآل

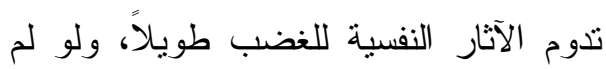
يكن المرء كذللك، لاحتاج إلى ممارسة العلاج
ا - صراع مع الآخرين الذين يعترضدن

على الغضب، أو الذين يتهددهم.

r- صر اع مع النفس؛ لأن الغضب يحرم

الفرد من العطف، و الحب، و الحنان، ويفقده السيطرة على نفسه.

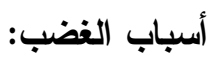

ا - حرمان الطفل من الاهتمام، و الرعاية، و المحبة، من قبل الكبار •

r- القسوة الثديدة، وحرمان الطفل من تلبية رغباته.

r- التدليل الزائد من قبل الو الدين؛ بحيث لا يرفض طلب للطفل، فكل طلباته

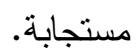
ع - إجبار الطفل على القيام بعمل ما لا له يحبه، أو تكليفه بأعمال تفوق طاقته،

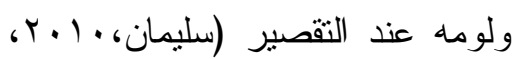

$\cdot(\wedge$.

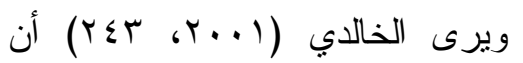
انفعال الغضب يرجع إلى أسباب منعددة؛ منها: أنه ينتج عندما يتعرض الفرد لظروف لئح إس الفثل، و الإحباط في تحقق أهدافه، و إثباع حاجاته الأساسية، كما يحدث نتيجة الاتكالية الزائدة التي يتصف بها سلوك بعض الأفر اد

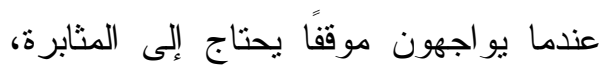
و الإنجاز ، و الاعتماد على النفس. 
- المساعدة على تنتيط المر اكز العصبية.

- شعور الفرد بتقدير الذات. - رد فعل دفاعي على تهديد الأنا.

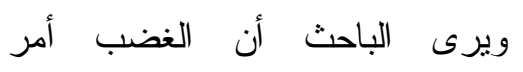

طبيعي، أوجده الله، وزوّد به الإنسان؛ ليدافع عن ذاته، ويعبر بها بر الأمان، بعيدًا عن الهان المشاكل التي تعترضها، وكل هذا من فو ائد الغضب الإيجابية.

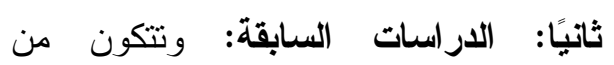

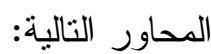

المحور الأول: دراسات تناولت أساليب المعاملة الوالدية وعلاقتها ببعض التفيرات:

هدفت در اسة تام، وشونق، وكدرفلو ،

Tam, C., Chong, A., وكـــــ Kadirvelu, A., \& Khoo, Y. (2012) إلى الكثف عن العلاقة بين أساليب المعاملة

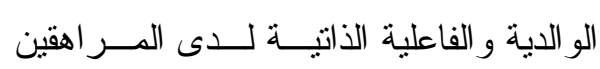

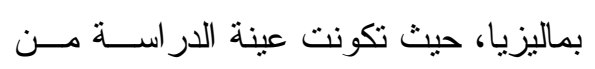

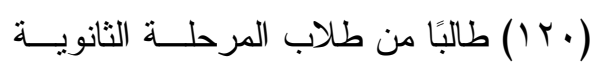

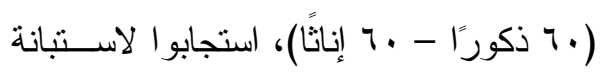

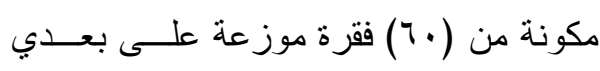
أساليب المعاملة، وتصور ات الفاعلية الذاتية،

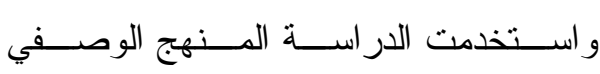

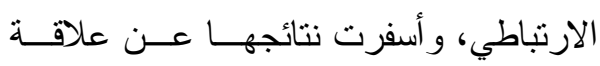

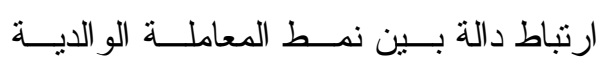
التسلطي وبين الفاعلية الذاتية لاى المر اهق؛ حيث يسهر بما نسبته (با (\%) من الفاعليــة

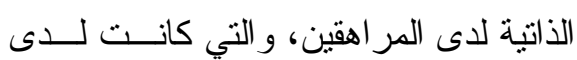

النفسي؛ للتخلص من هذا المرض (قطينة، . (I)

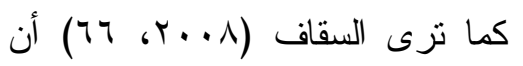

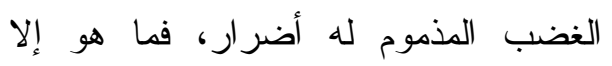
مرض حارق للعقل، ومانع يعمل على إعاقة إصدار القرارات الرشيدة في حق الفرد نفسه أولاً، وفي حق علاقته بالآخرين لاحقًا، لتحل

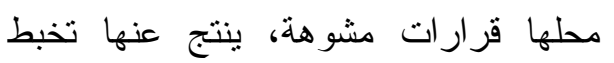
ونتشويه في إدار الك الموقف بأكمله، لذا لا بد بد من إخضاع الغضب تحت سيطرة العقل؛

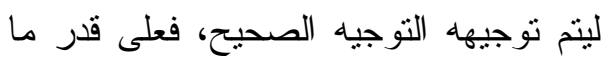

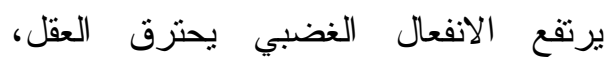

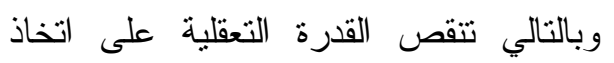

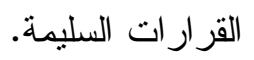
ويرى الباحث أن الغضب السلبي يؤثر على صحة الإنسان، ويخرجه من دائرة

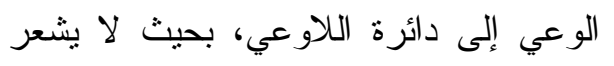
بما يفعله، مما يتسبب في أمور تصل دلى إلى بلى إيذاء النفس و الآخرين. الفوائد الإيجابية للغضب:

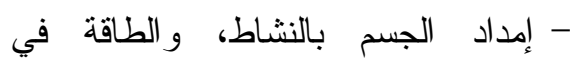
مواجهة المشكلة التي تعترض تكيف الفرد. - عمل' وظائف الغضب كمؤشرات تمييزية ترشد الجهود الر امية إلى حل المشكلة. - دفع الفرد للإنجاز و الإبداع. 
المساعدة في نشر ثقافة التسامح لدى الأبناء، ومدى شيوع تللك الثقافة في نفوسهم؛ حيـــث استخدم الباحث المنهج الوصــفي التحليلـي، وني،

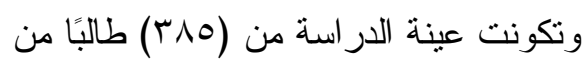

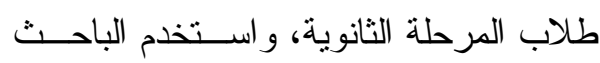

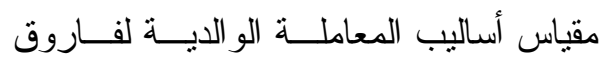

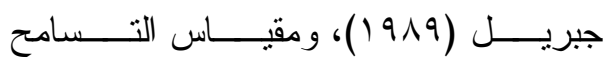

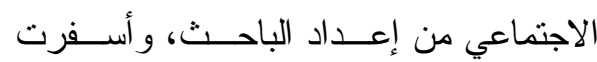
النتائج عن أن أكثر أساليب المعاملة الو الدية

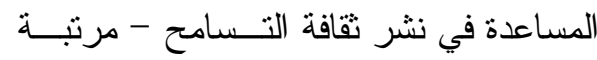

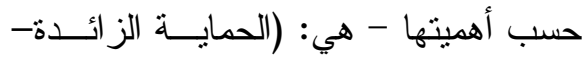

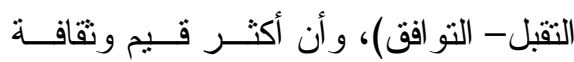

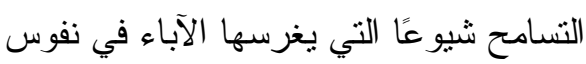

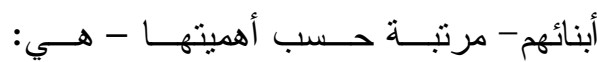
(التعاون- الحب- الصفح)، ويمكن التتبؤ من

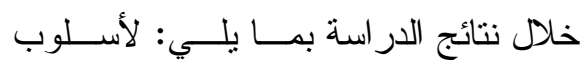

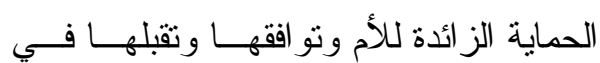

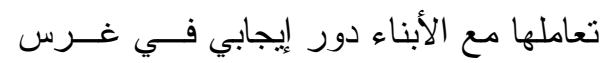

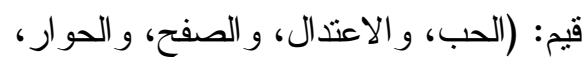

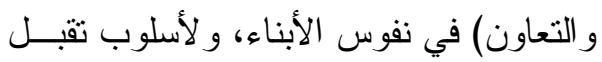

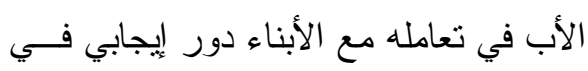

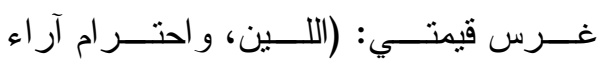

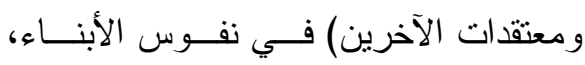
و لأسلوب الرفض و الحماية الز ائدة للأب في الان فئ

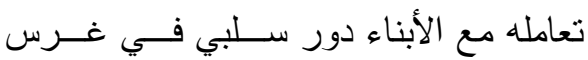
قيمتي: (الحوار، و التعاون) في نفوس الأبناء.
الذكور أعلى منها لدى الإناث؛ بسبب طبيعة التربية المتساهلة للإناث.

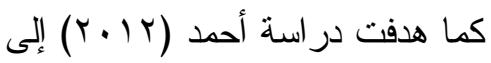
معرفة وقياس العلاقة بين أساليب المعاملـــة

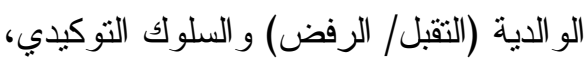
وكذلك التأكد من وجود فروق في منوسطات السلوك التوكيدي بين الجنسين، وللتحقق من هذه الدر اسة اعتمدت منهجيتها على استخدام

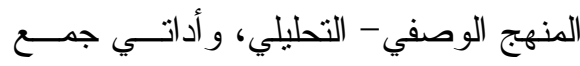
البيانات، و المتمتلنتين في اســـمارة المعاملـــة الو الدية لثافر و التي تتكون مسـن · ب بنــدًا

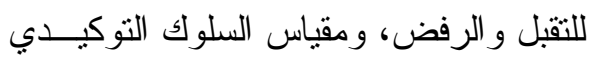
لر اثوس الذي يضم YV بندًا، وقد نم اختيــار

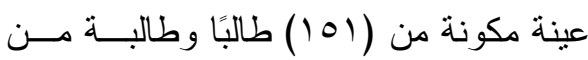
المرحلة الثانوية بطريقة عـشـو ائية طبقيـــة، وتوصلت الدر اسة إلى النتائج الآتية: وجــــود

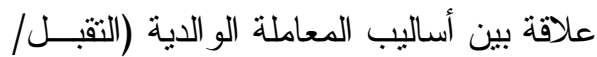
الرفض) كما يدركها الطـــلاب فــــي التعلــيم الثانوي و السلوك التوكيدي، ووجود علاقـــة موجبة طردية بين أساليب المعاملة الو الديــة

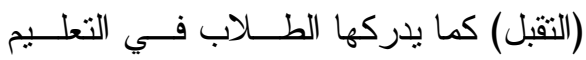

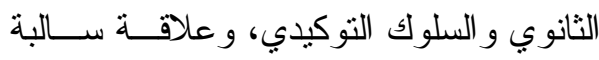

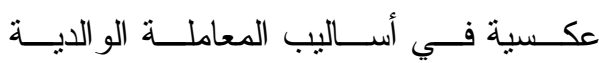
(الرفض) كما يدركها الطلاب فـــي التعلــيم الثانوي و السلوك التوكيدي.

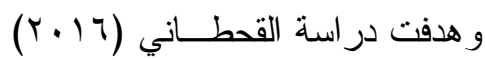
إلى معرفة أكثر أسـاليب المعاملـــة الو الديـــة 


\section{المحسور الثاني: دراسـات تناولت انفعسال الغـضب وعلاقته ببعض المتفيرات:}

وتضمن هذا المحور الدراسات التي تناولت انفعال الغضب، وجاعت على النحو التالي:

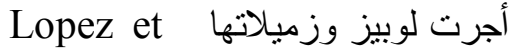

al. (2008) در اسة هدفت إلى الكثف عـن

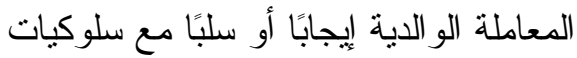

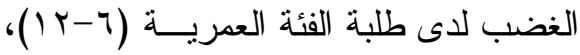
و اعتمدت منهجية الدر اسة علــى اســتخدام المنهج الوصفي- الارتباطي، كما استخدمت التهن

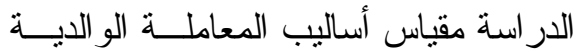
ومقياس الغضب، وتكونت العينة من (00؛)

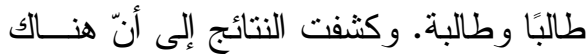
علاقة ارتباطية إيجابية بين سلوكيات التتشئة الجيدة (نمط التتـشئة الــديمقر اطي)، وبـين السلوكيات الاجتماعية الجيدة لدى هذه الفئة، كما أثنارت إلى أنّ ممارسات التنشئة الو الدية السلبية (منل نمط النتشئة التسلطي) تسهم في إنسات

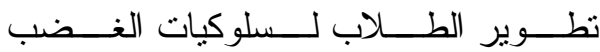

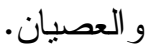

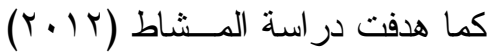

إلى التعرف على مستوى العلاقـــة الو الديــــة

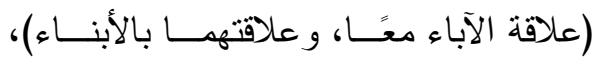

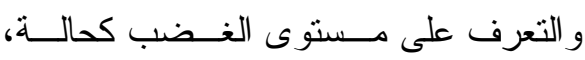

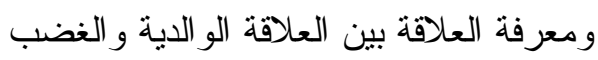

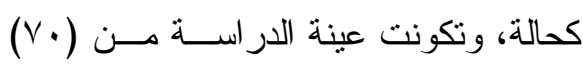
طالبة من طالبات المرحلة الثانوية، واعتمدت
وأجرت علي (Y. V أب) در اسة هدفت إلىى التعرف على أساليب المعاملة الو الديـــة كما يدركها الأبناء و علاقتها بالتو افق النفسي

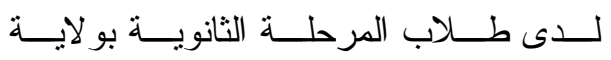
الخرطوم، ولتحقيق هدف الدر اسة اعتمــدت منهجية الدر اســة علــى اســـتخدام المــنهـج

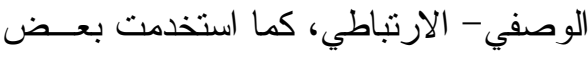

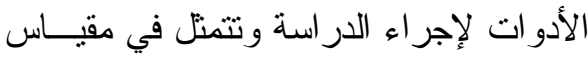

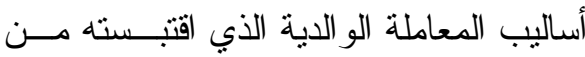
مقياس أماني عبد المقصود، ومقياس التوافق النفسي المعدل عن مقياس هيوم بل، المعدلين من قبل الباحثة، وقد تكونت عينة الدر اســـة

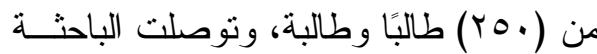
لعدد من النتائج؛ وهي: تتسم أساليب المعاملة

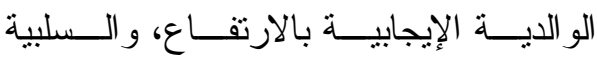
بالانخفاض، مع عدم وجود فروق ذات دلالة إحصائية في درجة أساليب المعاملة الو الديــة

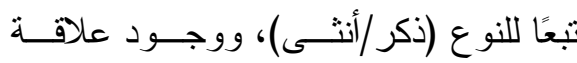

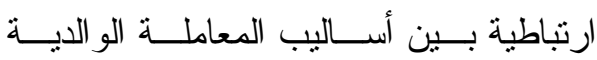

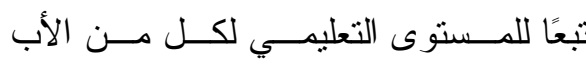
و الأم، و لا توجد فروق ذات دلالة إحـصائية في أساليب المعاملة الو الدية للآباء و الأمهات تبعًا لمتغيــر نـــوع المدرســة (نموذجيــة، جغر (فية). 
الغضب، تُعزى لمتغير الجــنس، ولــصالح

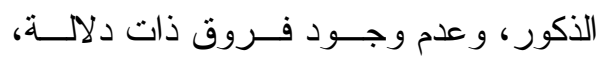
تُعزى لأثر الصف، ووجود علاقة ارتباطبــة

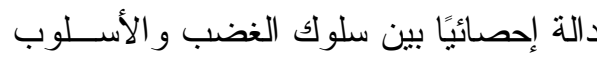

$$
\text { التسلطي. }
$$

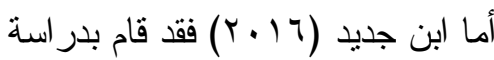

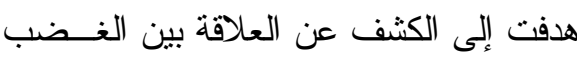

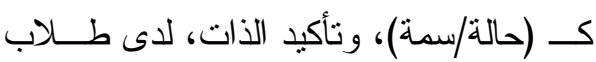

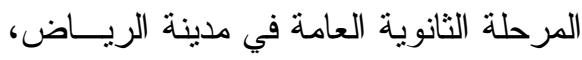

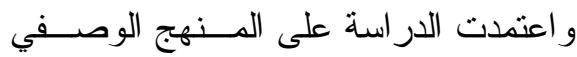
الارتباطي، و واستخدم الباحث مقياس الغضب على عينة الدر اسة المكونة من (• (ـ ا ) طالبًا من طلاب المرحلة الثانوية، ومقياس توكيــد

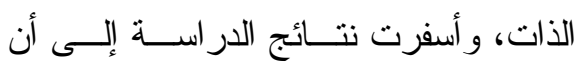

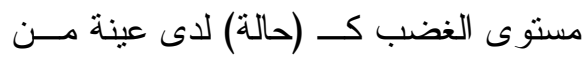

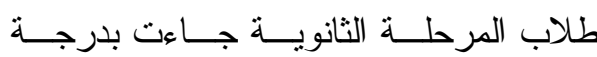

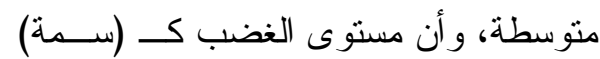
جاءت بدرجة مرتفعة لاى عينة من طــلاب

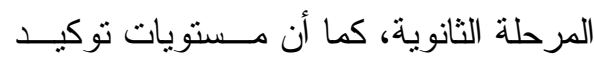
الذات لاى عينة من طلاب المرحلة الثانويـــة جاءت بدرجة منخفضة، بينما كثفت النتــائج النهائية عن وجود علاقة طردية ذات دلالة إحصائية بين مقياس الغضب كحالة، ومقياس الغضب كسمة، ووجود علاقة عكسية بـين

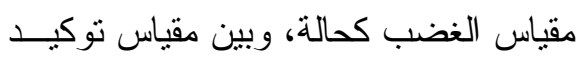

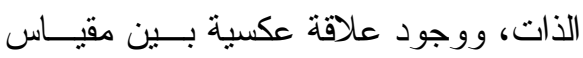
الغضب كسمة، وبين مقياس نوكيد الذات.
منهجية الدر اســـة علــى اســتخدام المــنهـج

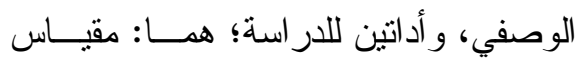
العلاقة الو الدية (من إعداد الباحثة)، ومقياس الغضب كحالة، وسمة (من إعداد محمد السيد

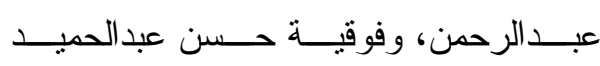

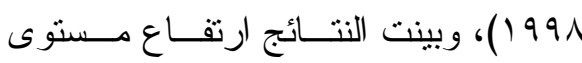

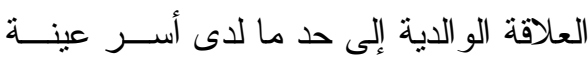

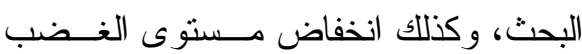
كحالة لدى عينة الدر اسة، وأن هناك علاقـــة ارنباطية عكسية بين مستوى العلاقة الو الدية وحالة الغضب لدى عينة الدر اســـة، وهـــــا يعني أنه كلما ارتفع مستوى العلاقات الو الدية

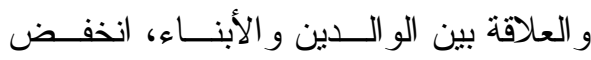
مستوى حالة الغضب لدى عينة الدر اسة.

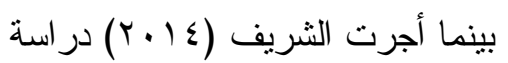
هدفت إلى الكــف عــن مـستوى ســلوك الغضب، و علاقته بأساليب التتشئة الأسـرية،

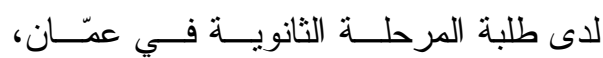
و اعتمدت منهجية الدر اسة علــى اســتخدام

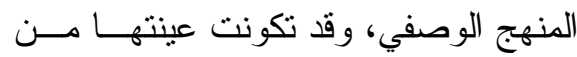

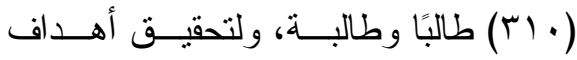
الدراسة نم إعداد مقيــاس الغــضب؛ حيـــ تكِّن من (9 (1) فقــرة، واســـتخدام مقيــاس لأساليب التتشئة الأسرية، ويحتوي على ثناثنة أبعاد؛ هي: الأسلوب الديمقر اطي، و الأسلوب

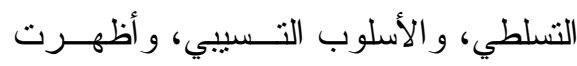

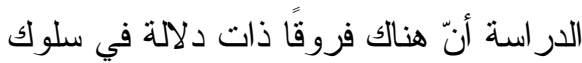




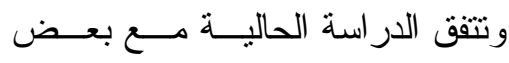

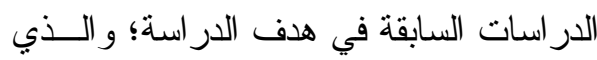

تحدد في التعرف على العلاقة بين أسـاليب

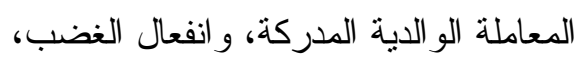

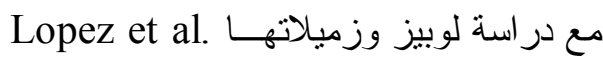

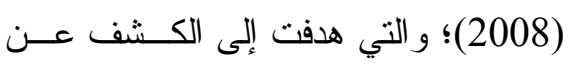

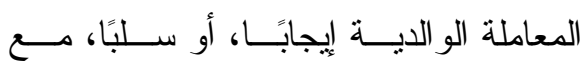

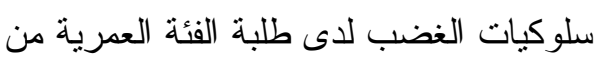

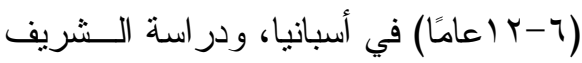

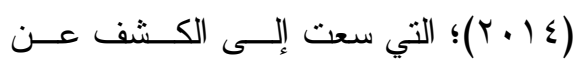

مستوى سلوك الغضب، و علاقتـــه بأســاليب

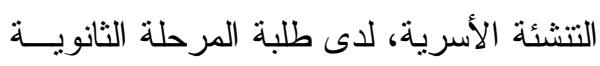

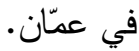

كما اتفقت هذه الدر اسة مــع بعـض

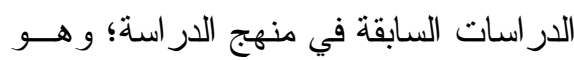

المنهج الوصفي - الارتباطي، مع در اســات

كل من: در اسة لوبيز وزميلاتها

Tam et al. (2008) ودر اسة تام وزملائه وزئهن

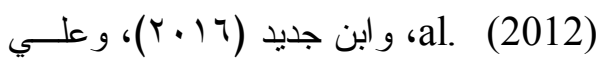

كما اتفقت الدراسة الحالية مع بعض

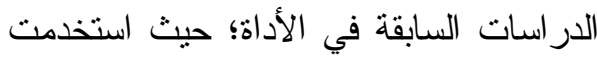

Lopez et al. دراسة لوبيز وزميلاتها (2008) مقياس أساليب المعاملة الو الدية،

ومقياس الغضب، كما استخدمت دراسة

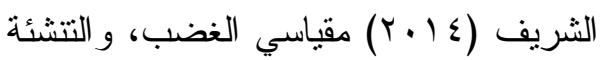

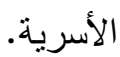

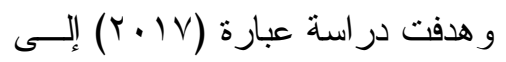

التعرف على العلاقة بين الأفكار اللاعقلانية،

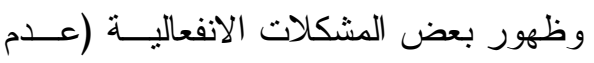

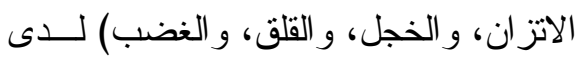

المر اهقين، وقد تضمنت العينة (بیr) طالبًا

وطالبة من طلاب المرحلة الثانويــة بمدينــة

حمص، و استخدم الباحث مقيــاس الأفكــار

اللاعقلانية (من إعداد بـشرى المغربــل)،

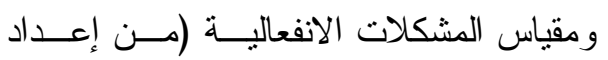

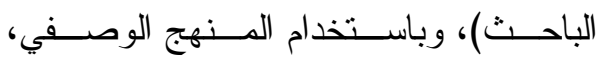

وكثفت نتائج الدراسة عن أنه نوجد علاقـــة

إيجابية دالة بين درجات الطلاب على مقياس

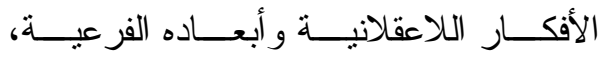

ودرجاتهم على مقياس المشكلات الانفعاليـــة

ككل و أبعاده الفرعية، كما توجد فروف داتئي

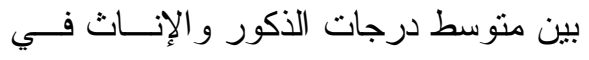

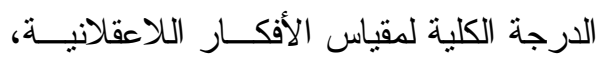
وفي المقاييس الفرعية الآتية: (المبالغة فـي لإلي

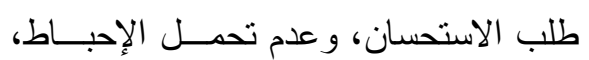

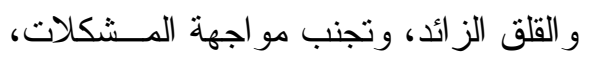

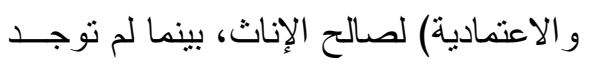
فروق في الأبعاد الأخرى لمقيــاس الأفكـار الإناس

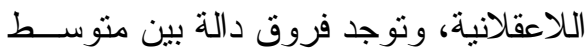
درجات الذكور و الإناث في بعض المشكلات

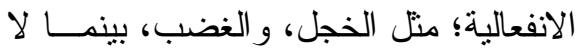

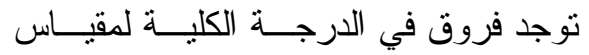

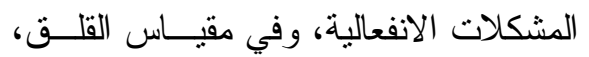

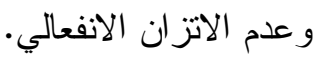


عينة من طلاب المرحلة الثانوية بمحافظـــة الليث، كما حدد الباحث الأساليب الإحصائية

المستخدمة لتفسير وتحليل بيانات الدر اسة.

- منهج الدراسة: المنهج الوصــفي فـي صورته الارنباطية.

- مجتمع الدراسة: تمنتل مجتمع الدر اســـة

في طلاب المرحلة الثانويــــة بمحافظــــة الليث، و البالغ عددهم (q9 (r) طالبًا. - عينة الدراسة: قام الباحث باختيار عينة الدر اسة حيث بلغ حجمها (س ب) طالبًّا من طلاب المرحلة الثانويـــة بمحافظـــة الليث، وتم اختيار ها بالطريقة العشو ائية من مجتمع الار اسة.

ويوضح الجدول (1) إحصائية بعـدد

المدارس و الطلاب فــي المرحلــة الثانويـــة

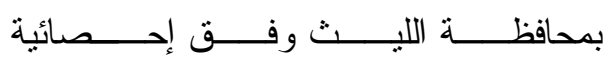
$: \rightarrow 1 \leqslant \mu / / \leqslant r \wedge$

جدول (1) إحصائية مجتمع الدر اسة

\begin{tabular}{|c|c|}
\hline المرحلة الثانوية & بيان الإحصائية \\
\hline$r \varepsilon$ & عدد المدارس \\
\hline rrqq & عدد الطلاب \\
\hline
\end{tabular}

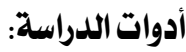

تكونت أدوات الدر اسة من المقاييس الآتية: ـ - مقياس أساليب المعاملة الو الدية. r - مقياس انفعال الغضب.
واختلفت الدراسة الحالية مع معظم

الدر اسات السابقة في أداة الدر اسة؛ فدر اسات كل من: أحمد (Y (Y)؛ استخدمت استمارة المعاملة الو الدية، ومقياس السلوك التوكيدي، وتام وزملائه (2012) (Tam et al. استخدمت مقياس أسـاليب المعاملة الو الدية، ومقياس الفاعلية الذاتية، وريفرز وزملائه Rivers et al. (2012) الفاعلية الأكاديمية الذاتية، بجانب مقياس

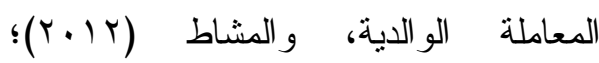
استخدمت مقياس العلاقة الوالدية، ومقياس

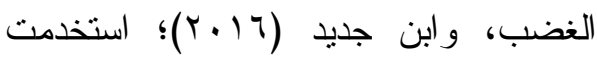
مقياس توكيد الذات، بجانب مقياس الغضب،

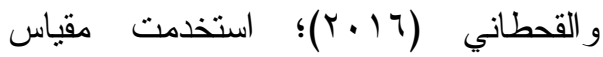
أساليب المعاملة الو الدية، ومقياس التسامح الاجتماعي، وعلي (Y.IV)؛ استخدمت مقياس التوافق النفسي، بجانب مقياس أساليب المعاملة الو الدية. إجرائات الدراسة:

تتاول الباحث الإجــر اءات المنهجيــة التي أتبعت في هذه الدر استة؛ لتحقيق أهدافها، حيث تتاول المنهج المستخدم، ومجتمع وعينة

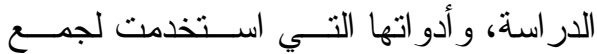
البيانات الأولية، من حيث إجر اءات بنائهـــا، و اختبار صدقها، وثباتها؛ ثم بيّن كيفية اختيار

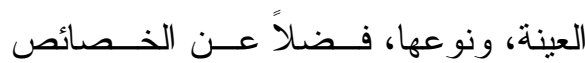
الديمو غر افية لعينة الدر اسة؛ التي تمثلت فـي 
أولاً: مقياس أساليب المعاملة الوالدية: صدق الاتساق الداخلي لمقبــاس أســاليب

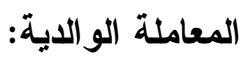

تم التحقق من صدق الاتساق الداخلي

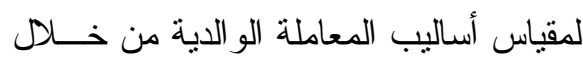

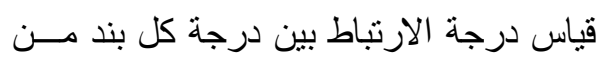

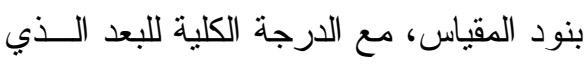

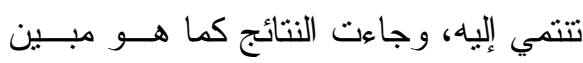

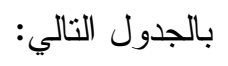

$$
\text { إجراءات الصدق والثبات لأدوات القياس: }
$$

للتحقق من مؤشر ات الصدق و الثبات

لأدو ات القياس، قام الباحث بنطبيق الأدوات مؤنرات

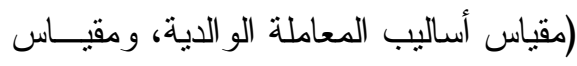

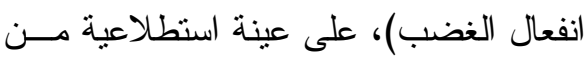

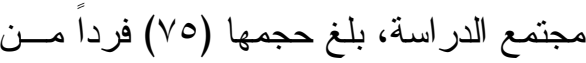

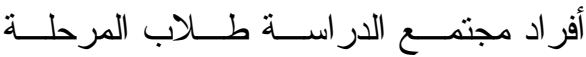
الثانوية، وفيما يلي مؤشر ات الصدق و الثبات للمقاييس المستخدمة في الدر اسة الحالية:

جدول (r)

معاملات ارتباط بنود مقياس أساليب المعاملة الوالدية بالارجة الكلية للبعد المنتمية إليه

\begin{tabular}{|c|c|c|c|c|c|c|c|c|}
\hline \multicolumn{4}{|c|}{ صورة الأم } & \multicolumn{4}{|c|}{ صورة الأب } & \\
\hline معامل الارتباط & م & معامل الارتباط & م & معامل الارتباط & b & معامل الارتباط & م & \\
\hline$* *, T \vee r$ & 19 & $* * .091$ & 1 & $* *, \vee \leq q$ & 19 & $* *, 0 \wedge \Lambda$ & 1 & \multirow{4}{*}{ الرفض التقبل } \\
\hline$* *, \vee \vee 0 \leq$ & $r T$ & $* *, \Gamma \cdot \Lambda$ & 7 & $* *, 7 \wedge \mathrm{V}$ & rT &., $.97 \mathrm{~V}$ & 1 & \\
\hline \multirow[t]{2}{*}{$* *, 507$} & m & $* *,\{\rceil\rceil$ & 1. & $* *, 0 \wedge \wedge$ & 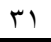 & $* *, \vee \backslash \wedge$ & 1. & \\
\hline & & $* *, 09$. & 10 & & & $* *, 0 \leqslant r$ & 10 & \\
\hline$* *, v \cdot 1$ & $r \varepsilon$ & $* *, 0 . \varepsilon$ & $r$ & $* *, 071$ & $r \varepsilon$ & $* *, 719$ & $r$ & \multirow{4}{*}{ الإلهمال } \\
\hline$* *, 091$ & $r V$ & $* *, 7,7$ & V & $* *, 0 \vee \varepsilon$ & rV & $* *, 07 \varepsilon$ & v & \\
\hline \multirow[t]{2}{*}{$* *, 0 \cdot r$} & rT & $* *, 7 . \Sigma$ & 11 & $* *, \Sigma \wedge r$ & rt & ***, • T צ & 11 & \\
\hline & & $\cdot, 1 \mathrm{VI}$ & $r$. & & & **, r r Y O & $r$. & \\
\hline ***,,$\vee T r$ & r) & $* *, \Sigma \wedge$. & $r$ & $* *, \vee \vee १ \wedge$ & r) & $* *, 09$. & $r$ & \multirow{3}{*}{ التسوة القسام/ } \\
\hline$* *, \vee V \vee V$ & rA & $* *, 0 \vee 9$ & $1 Y$ & $* *, \vee \cdot q$ & rA & $* *, 7 \vee 1$ & Ir & \\
\hline$* *, 071$ & r & $* *, 711$ & 17 & *** & rT & $* *, \leq 7 \pi$ & 17 & \\
\hline$* *, 7 \vee \varepsilon$ & rr & $* *, 7 \pi$. & $\varepsilon$ & $* *, \vee \leq \varepsilon$ & $r r$ & $* * \cdot, \wedge 9$ & $\varepsilon$ & \multirow{4}{*}{ التفرقاو اة/ } \\
\hline$* *, 011$ & ro & ***, ו ו ו & $\Lambda$ & $* *, 01$ & ro & $* * .099$ & $\Lambda$ & \\
\hline$* *, 710$ & rq & $* *, 0 \leqslant Y$ & $1 \pi$ & $* *, 0 \leqslant \wedge$ & $r 9$ & $* *, 7 \vee \varepsilon$ & $1 \pi$ & \\
\hline$* *, 7 \backslash \Lambda$ & $r \varepsilon$ & $* *, \vee \vee q$ & IV & $* *, V T$. & $r \varepsilon$ & **, TV. & IV & \\
\hline$* *, 07 r$ & rT & ***, & 0 & $* *, V \vee V$ & $r r$ & $* *, \mathrm{~V} V \mathrm{~V}$ & 0 & \multirow{4}{*}{ الديمقر اطية| } \\
\hline$* *, \leqslant \vee 0$ & $r$. & ***, & 9 & ***, • & $r$. & $* *, 749$ & 9 & \\
\hline \multirow[t]{2}{*}{$* *, O Y V$} & ro & $* *,, \Sigma \Lambda \leq$ & $1 \varepsilon$ & ***, & ro & $* *, T / \mathrm{V}$ & $1 \varepsilon$ & \\
\hline & & $* *, T Y \varepsilon$ & 11 & & & $* *$, * $\{\wedge$ 人 & 11 & \\
\hline
\end{tabular}

* *تير إلى أن معامل الارتباط دال إحصائيًا عند مستوى المعنوية (1 +, •). 


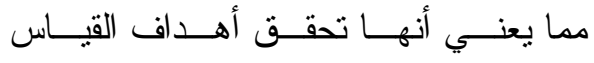

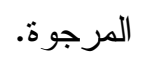

كما قام الباحث بحسـاب معساملات

ارتباط بيرسون؛ لقياس درجة الارتباط بين

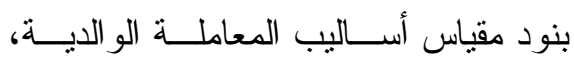

بالدرجة الكلية للمقياس، وجاءت النتائج كما

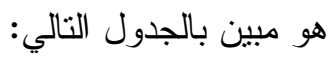

يتضح من النتائج بالجدول أعــلاه أن

جميع فقرات مقياس أساليب المعاملة الو الدية

تتمتع بدرجة مرتفعة من الارتباط مع البعد

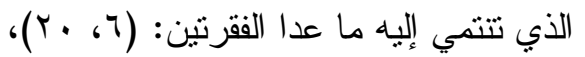

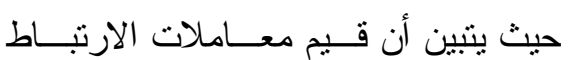

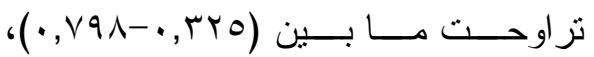

وبالتالي فإن جميع هذه الفقر ات نرتبط بشكل

معنوي وجوهري مع البعد الذي تتنمي إليه،

جدول (r)

معاملات ارتباط بنود مقياس أساليب المعاملة الوالدية بالدرجة الكلية للمقياس

\begin{tabular}{|c|c|c|c|c|c|c|c|}
\hline \multicolumn{8}{|c|}{ الصورة } \\
\hline \multicolumn{4}{|c|}{ صورة الأم } & \multicolumn{4}{|c|}{ صورة الأب } \\
\hline معامل الارتباط & 5 & معامل الارتباط & p & معامل الارتباط & ? & معامل الارتباط & 5 \\
\hline$* *, \uparrow \wedge 0$ & 19 & $* *,\{9 \vee 1$ & 1 & $* *, 7 \vee \wedge$ & 19 & $* *, 010$ & 1 \\
\hline . , 1 Y - & $r$. & $* *, 0 \leqslant V$ & r & $\cdot, \cdot 10 \leqslant-$ & $r$. & $* \%, T \vee$. & $r$ \\
\hline$* *, 0 \wedge \Lambda$ & Y) & *., rq & $r$ & $* *, \mathrm{~V} \wedge \Lambda$ & Y) & $* *, \varepsilon \vee \leqslant$ & $\mu$ \\
\hline$* *, v \Gamma \mu$ & rY & $* *, 00 Y$ & $\varepsilon$ & $* *, \vee \vee 70$ & rY & $* *, \vee \vee \vee \varepsilon$ & $\varepsilon$ \\
\hline ***,,$\leqslant\rceil \Sigma$ & r & $* *, 091$ & 0 & $* *, \uparrow \wedge$. & r & $* *, \vee \wedge \vee$ & 0 \\
\hline$* *, 71 \mathrm{~V}$ & $r \varepsilon$ & $\cdot, 1 \times 9$ & 7 & **, & $r \varepsilon$ & $\cdot, 1 \cdot \leq-$ & 7 \\
\hline ***, & ro & $* *, \leqslant 90$ & V & $* *, 00 \mathrm{~V}$ & ro & $* \%, r q$. & V \\
\hline **, T1. & rT & $* *, T \backslash V$ & $\wedge$ & **, TrV & rT & $* *, 0, r$ & $\Lambda$ \\
\hline$\cdot, r \cdot q$ & YV & $* *, 70 \mathrm{~V}$ & 9 & $\cdot, Y 17$ & rV & $* *, 011$ & 9 \\
\hline **,,$V M I$ & rᄉ & $* *, \leq 11$ & 1. & $* *, 7 \leq r$ & rᄉ & $* *, 717$ & 1. \\
\hline$* *, O Y$. & rq & $* *, r \cdot 1$ & 11 & $* *, 01 \leqslant$ & rq & $* *,, \Sigma \varepsilon r$ & 11 \\
\hline$* *$, rqv & $r$. & $* *, r \leq 9$ & ir & $* *, 019$ & $r$. & $* *, \leq 90$ & 14 \\
\hline$\% *, 071$ & M & $* *, 01 \varepsilon$ & 14 & $* \%,\{90$ & r & $* *, 7 \wedge \wedge$ & $1 \pi$ \\
\hline$* *, \leqslant 07$ & rr & $* *, \leqslant 90$ & $1 \varepsilon$ & $* *, \Sigma \Gamma \wedge$ & Tr & $* *, T \vee \neg$ & $1 \leq$ \\
\hline **, OrY & זr & $* *, 0 \vee 0$ & 10 & **, TY人 & זr & $* *, \Sigma \Lambda \mu$ & 10 \\
\hline **, oYo & $\Gamma \varepsilon$ & $* *, T \leq \Gamma$ & 17 & ***, 77 . & $\Gamma \varepsilon$ & 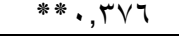 & 17 \\
\hline ***, & ro & $* *, \uparrow \wedge$. & IV & **, * & ro & $* *, 0 \vee r$ & IV \\
\hline & & $* \%$, O Y O & 11 & & & $* *, 199$ & 11 \\
\hline
\end{tabular}

* تثير إلى أن معامل الارتباط دال إحصائًًا عند مستوى المعنوية (0. . .).

** تشير إلى أن معامل الارتباط دال إحصائيًا عند مستوى المعنوية (1 ., •). 


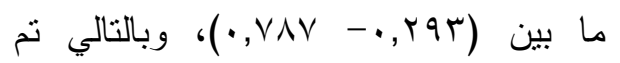

يتضح من المؤشر ات بالجدول (r) أن

حذف الفقرات غير المرتبطة؛ وذلك لأنها قد وبن

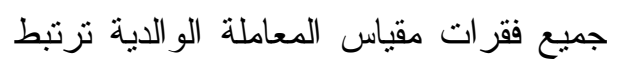
تسبب خلًا في نبات المقياس. وقد قام الباحث مع الدرجة الكلية للمقياس، ما عدا الفقرات: بحساب درجة الارنباط بين كل بعد من أبعاد (TV.T.،T)

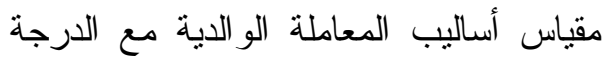

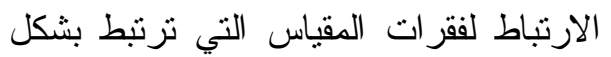
معنوي مع الدرجة الكلية للمقياس نراوحت الكلية للمقياس::

جدول ( ) معاملات ارتباط أبعاد مقياس أساليب المعاملة الو الدية بالدرجة الكلية للمقياس

\begin{tabular}{|c|c|c|}
\hline صورة الأم & صورة الأب & الصورة \\
\hline معامل الارتباط & معامل الارتباط & البعد \\
\hline$* *$ * ^ ^〉. & 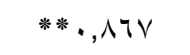 & التقبل/الرفض \\
\hline **,VIr & $* *, 79 \leq$ & الر عاية/الإهمال \\
\hline$* *, \wedge T r$ & $* *, \wedge \vee \varepsilon$ & التسامح/القسوة \\
\hline$* *, 94$. & $* *, 9 \leq 1$ & المساو اة/التفرقة \\
\hline$* *, 9 \ldots$ & $* *, 9 . r$ & الديمقر اطية/التسلط \\
\hline
\end{tabular}

* *تير إلى أن معامل الارثباط دال إحصائيًا عند مستوى المعنوية (1 .,.•). ثبات مقياس أساليب المعاملة الو الاية:

جدول (0) معاملات الثبات الكلي والمحاور لمقياس أساليب المعاملة الوالدية

\begin{tabular}{|c|c|c|c|}
\hline \multicolumn{2}{|c|}{ معامل ثبات ألفا كرونباخ } & \multirow{2}{*}{ عدد البنود } & \multirow[t]{2}{*}{ الصورة } \\
\hline صورة الأم & صورة الأب & & \\
\hline$\cdot, \mathrm{V} \varepsilon$ & $\cdot, \wedge$. & 7 & ل التقبل/الرفض \\
\hline$\cdot, 70$ & זו, & 0 & 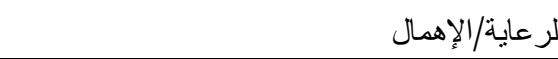 \\
\hline$\cdot, \mathrm{VV}$ & $\cdot, \mathrm{V} \leq$ & 1 & التسامح/القسوة \\
\hline$\cdot, \wedge)$ & $\cdot$, Ar & $\wedge$ & ل ل لمساو اة/التفرقة \\
\hline$\cdot, 77$ & $\cdot$, vo & $v$ & ل لديمقر اطية/التشلط \\
\hline • & $\cdot, 9 \leqslant$ & rr & الثبات الكلي لمقياس أساليب المعاملة الو الدية \\
\hline
\end{tabular}


عالية من الثبات، تفوق الحد المـسموح بــهـ لثبات أدو ات القياس المقدرة بـــ (• V., ). ثانيًا: صدق وثبات مقياس الغضب: صدق الاتساق الاخلّي لمقياس الغضب: من أجل التحقق من مؤشرات الصدق لمقياس الغضب، تم حساب معاملات ارتباط بيرسون؛ وذلك لقياس درجة الارنباط بين بنود مقياس الغضب مع الدرجة الكلية للبعد

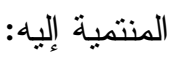

تم حـسـاب ثبــات مقيــاس أســاليب

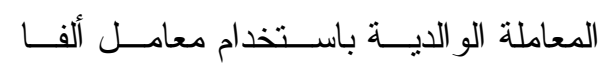
كرونباخ، بعد حذف العبار ات غير المرنبطة؛

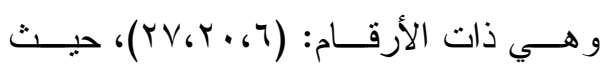

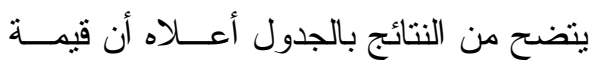

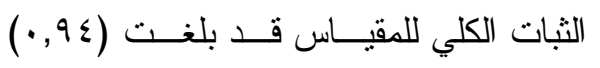
لصورة الأب من المقياس، بينما بلغت قيمــة لكنة

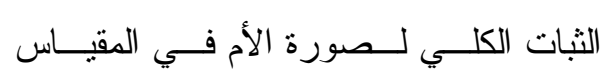

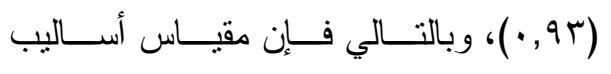
المعاملة الو الدية في صورنيه قد حقق درجة جدول (7)

معاملات ارتباط بنود مقياس الغضب بالدرجة الكلية للبعد المنتمية إليه

\begin{tabular}{|c|c|c|c|c|c|c|}
\hline معامل الارتباط & 5 & معامل الارتباط & 5 & معامل الارتباط & م & البعد \\
\hline$* *, 770$ & 11 & $* \%, 0 \vee 7$ & 7 & $* *, \quad \leq \leqslant \Sigma$ & 1 & \multirow{5}{*}{ استثارة الغضب } \\
\hline$* *, 7 \wedge 9$ & ir & $* *, 0 \wedge \wedge$ & V & $* *, 7 \cdot \Lambda$ & r & \\
\hline$* 0,099$ & Ir & $* *, 7 \vee 9$ & $\wedge$ & $* *$, or 7 & r & \\
\hline \multirow[t]{2}{*}{$* *, \leq 9 \leq$} & 11 & $* *, \_\wedge \wedge$ & 9 & ***, VNI & $\varepsilon$ & \\
\hline & & $* *, 7 \wedge 9$ & 1. & $* *, 7 \wedge \uparrow$ & 0 & \\
\hline$* *$, or $~ r$ & $r v$ & $* *, \tau \wedge r$ & rr & $* *, \Sigma \wedge$. & 19 & \multirow{4}{*}{ المو اقف المولدة } \\
\hline \multirow[t]{3}{*}{$* \%, 09 \leqslant$} & rᄉ & $* *, 70 \mathrm{~V}$ & $r \leq$ & $* *, T 1 \Gamma$ & $r$. & \\
\hline & & **, & ro & $* *, 7 r$. & r) & \\
\hline & & **, ory & ru & $* *, \vee \vee q$ & r & \\
\hline \multirow[t]{3}{*}{ ***, VRr } & iv & $* *, 70 r$ & $1 \leq$ & $* *, \mathrm{~V} \circ \mathrm{V}$ & 1. & \multirow{3}{*}{ استمر ارية مشاعر } \\
\hline & & $*, Y Y I$ & 10 & $* *, V \backslash \Gamma$ & 11 & \\
\hline & & $* *$, . $\Sigma \vee V$ & 17 & $* *, 774$ & ir & \\
\hline
\end{tabular}

* تشير إلى أن معامل الارنباط دال إحصائيًا عند مستوى المعنوية (0., •). * *تشير إلى أن معامل الارتباط دال إحصائيًا عند مستوى المعنوية (1 ., •). 
طلاب المرحلة الثاتويــة بمحافظـــة

$$
\text { الليث؟ }
$$

وتفرع من هذا السؤال الأســـئلة الفرعيــة

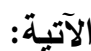

1 - ـ ما مستوى أساليب المعاملة الو الدية

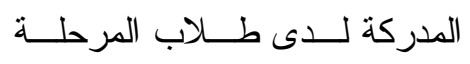

الثانوية بمحافظة الليث؟

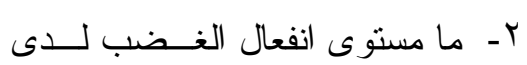

طلاب المرحلة الثانوية بمحافظـــة

$$
\text { الليث؟ }
$$

r- هل توجد علاقــة ارتباطيــة دالـــة

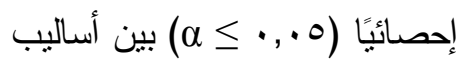

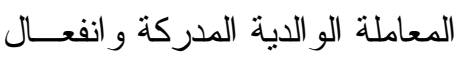

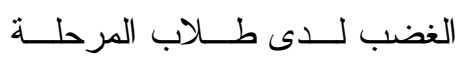$$
\text { الثانوية بمحافظة الليث؟ }
$$

النتائج المتعلقة بالسؤال الأول والأي ينص على: "ما مستوى أساليب المعاملة الو الدية

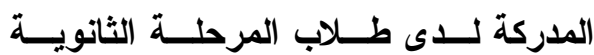
بمحافظة الليث؟".

للإجابة عن هذا السؤ ال؛ قام الباحــث بحساب المتوسطات الحسابية، و الانحر افــات المعيارية لأبعاد مقيــاس أســاليب المعاملـــة

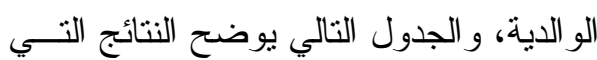
تم التوصل لها:
كثفت النتائج بالجدول (†) مؤشرات الصدق لمقياس انفعال الغضب، حيث يتضح

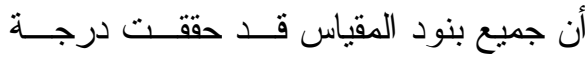

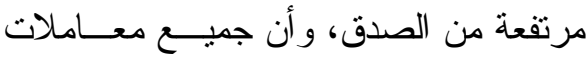

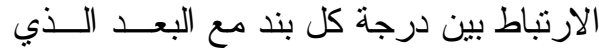
يتتمي إليه ذات دلالة إحصائية.

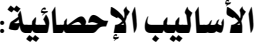

لتحليل بيانات الدر اسة تــم اســتخدام

الأساليب الإحصائية الوصفية و الاســــلالية، حيث شملت الأساليب الإحصائية الوصـفية الإلية الإلية

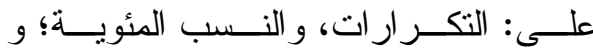
المتوســـــات الحــــــابية، و الاتحر افــــات

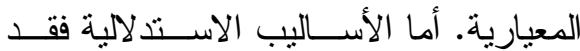
اشتملت على: تحليل التباين الأحادي الاتجاه،

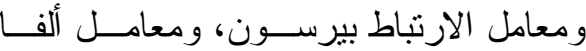

$$
\text { كرونباخ. }
$$

\section{نتائج الدراسة وتفسيرها ومناقشتها:}

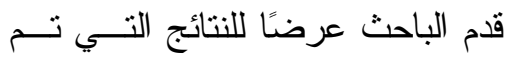

التوصل إليها وفقًا لما أسفرت عنه المعالجات

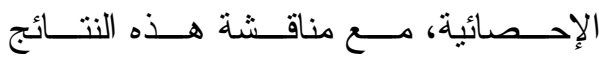

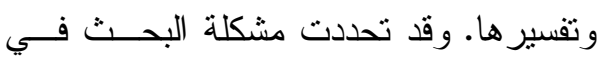
التساؤل الرئيس الآتي: ونئ وفئ

- هل هل هـــاك علاقـــة ارتباطيــة دالـــة إحصائيًا (ه . , . $\alpha \leq$ ) بين أســاليب المعاملة الو الاية وانفعال الغضب لاى الدان 
جدول (v)

المتوسطات الحسابية لاستجابات عينة الدراسة على أبعاد مقياس أساليب

المعاملة الو الاية مرتبة تنازليًا

\begin{tabular}{|c|c|c|c|c|c|c|c|}
\hline \multicolumn{3}{|c|}{ صورة الأم } & \multirow[b]{2}{*}{ الأبعاد } & \multicolumn{3}{|c|}{ صورة الأب } & \multirow[b]{2}{*}{ الأبعاد } \\
\hline الترتيب & الالمعياري & الحسابي & & الترتيب & الاحعراف & الحسابي & \\
\hline 1 & . rr & $r, O V$ & التقبل/الرفض & 1 & דיז, & $r, 0 \leqslant$ & التقبل/الرفض \\
\hline r & . r r & r,or & المساو اة/التفرقة & r & .rv & $r, \varepsilon \vee$ & المساو اة/التفرقة \\
\hline r & . ro & r,or & الرعاية/الإهمال & r & $\cdot, r v$ & $r, \leq 0$ & الرعاية/الإهمال \\
\hline$\varepsilon$ & ., ro & $r, \varepsilon)$ & الديمقر اطية/التسلط & $\varepsilon$ & • r rV & $r, r q$ & الايمقر اطية/التسلط \\
\hline 。 & $\cdot, \varepsilon$. & r,ro & التسامح/القسوة & 。 & 织 & $r, Y_{T}$ & التسامح/القسوة \\
\hline & $\cdot$, ro $_{0}$ & $r, \S \wedge$ & & & $\cdot, Y Y$ & $r, \varepsilon r$ & لمقياس أساليب الدارجة الكلية \\
\hline
\end{tabular}

* يشير إلى أن المتوسط من ب درجات.

المدركة من جانب طلاب المرحلة الثانويـــة

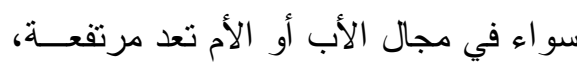

بينّا

على الرغم من تفوق أســاليب معاملـــة الأم الام

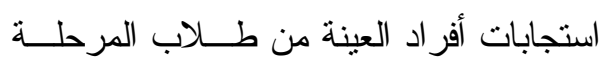

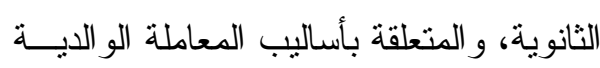
على أساليب معاملة الأب، وهذا أمر طبيعي؛ حيث إن الأم هي الأكثر عطفًا، و الأكثر حنانًا

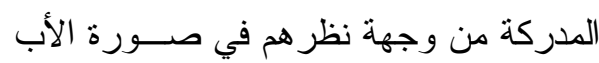

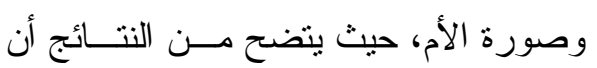

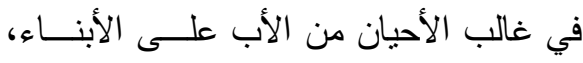
وذلك بحسب التركيبة النفسية و العاطفية لهــا تجاه أبنائها.

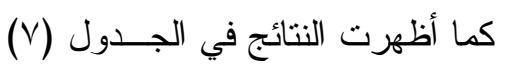

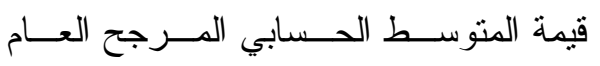

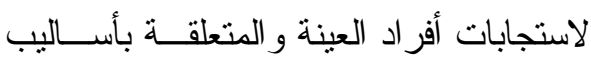

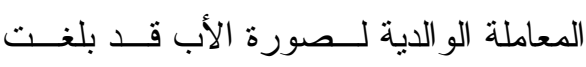
(Y,

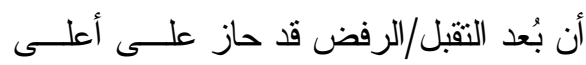

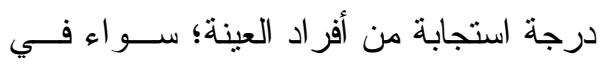

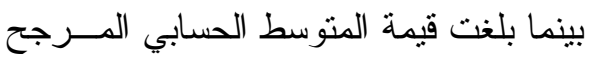
العام لاستجابات أفر اد العينة المتعلقة بأساليب

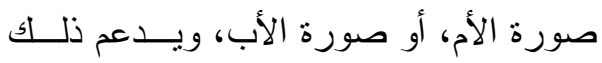
قيمة المتوسط الحسابي المرجح حيث بلغـــت الاب، ونس

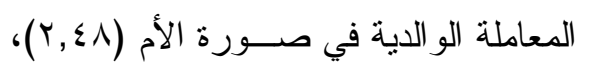
وبالثالي فإن مستوى أساليب المعاملة الو الدية 
وتدعم ذللك قيمة المتوسط الحسـسابي؛ حيــث

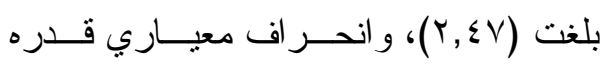

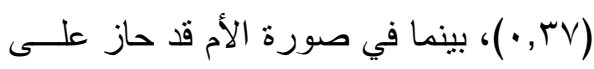
المرتبة الثالثة بمتوسط حسابي قدره (Y,OY (Y)، و انحر اف معياري قدره (هץ, • )، وبالتــالي فإن هنالك تأثيرًا لبعد المساو اة/التقرقة ســـــاء من جانب الأم أو الأب على الأبناء، وتــأثنير

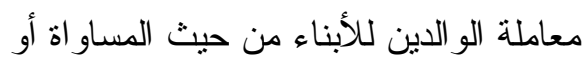
التفرقة، ولذلك هناك إدر الك بدرجة مرتفعــة

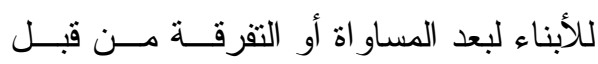
الو الدين، مما يؤثر على سلوكهم؛ سواء أكان

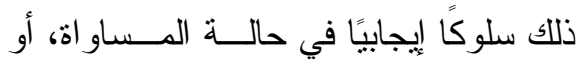
سلبيًا في حالة التقرقة.

وأوضحت أن بعد الديمقر اطية/التسلط

قد نال المرتبة الر ابعة من بين أبعاد مقيـــاس

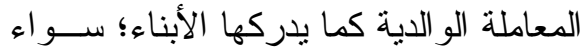

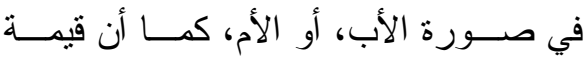

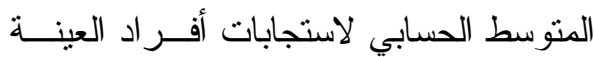

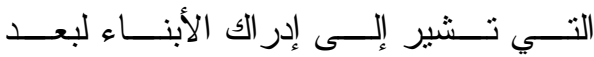
الديمقر اطية/ التسلط في صورة الأم قد بلغت

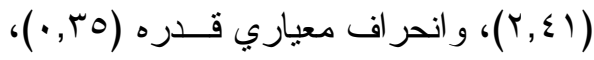
بينما بلغت قيمة المتوسط الحسابي في صورة ورة

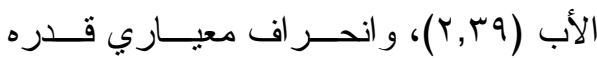

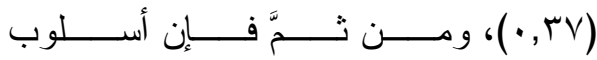

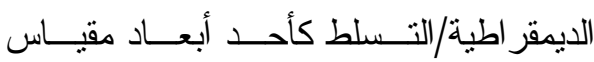
المعاملة الو الدية له أثز بدرجة كبيرة علـى لـى سلوك الأبناء، ولذلك بدرك الأبناء تأثنير كـلـل
في صورة الأم (Y,OV)، و انحر اف معياري

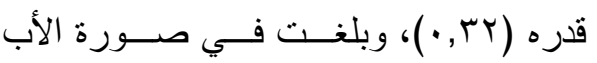
(

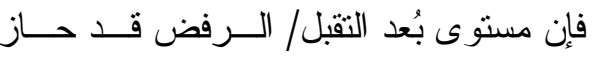
المرتبة الأولى في صورة الأب وصورة الأم بين الأبعاد الأخرى لمقياس أساليب المعاملة

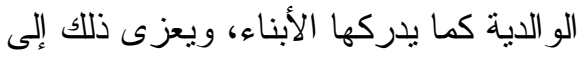
أن هنالك تأثيرًا بدرجــة مرتفعــة لممارســـة

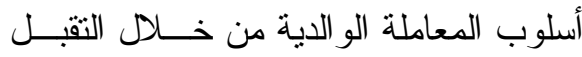

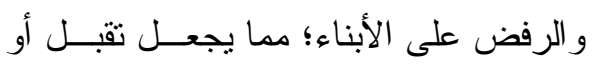
رفض الأبناء لهذا الأسلوب على درجة علداء عالية

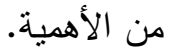
وكثفت النتائج في الجـدول (v) أن البعد الثاني الرعاية/الإهمال في صـــورة الأم قد حاز على المرنبة الثانية، بينما في صورة الأب قد حل في المرتبة الثالثة من بين أبعاد

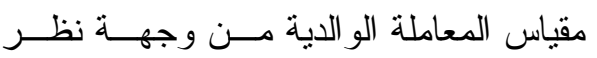
الأبناء، وتدعم ذلك قيم المتوسطات الحسابية لوجهات نظر أفر اد العينة؛ حيث جاءت على الى الئ

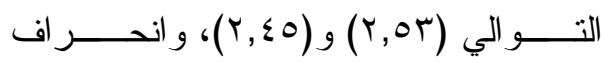

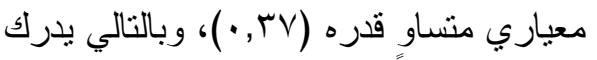

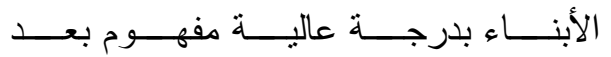

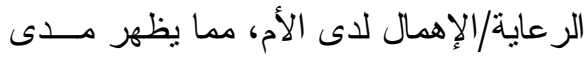

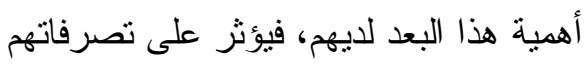
بالإيجاب أو السلب. كما أبانت أن بعد المساو اة/التفرقة قد

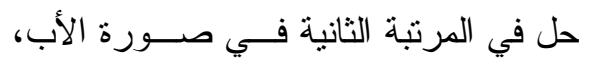


المعيارية لأبعاد مقياس الغضب، و الجــدول

النالي يوضح النتائج التي نم التوصل لها:

جلول (^)

المتوسطات الحسابية وترتيبها تنازليًا لارجات

\begin{tabular}{|c|c|c|c|}
\hline الترتيب & المعياري & الحسابي "المتوسي & الأبعاد \\
\hline$r$ & $\cdot, v \varepsilon$ & r,YY & استثارة الغضب \\
\hline 1 & $\cdot, 9$. & $r, \wedge \varepsilon$ & المو اقف المولدة للغضب \\
\hline r & $\cdot, 10$ & $r, \varepsilon V$ & الســـتمر ارية مــشاعر \\
\hline & ·, 79 & $r, \leqslant 9$ & الدرجة الكلية ليقياس \\
\hline
\end{tabular}

* تشبر إلى أن المتوسط من 0 درجات.

كثفت النتائج فــي الجــدول (^) أن

مستوى انفعال الغضب لدى طلاب المرحلــــة

الثانوية بمحافظة الليث، حيث يتضح أن قيمة

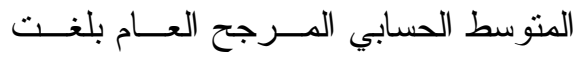

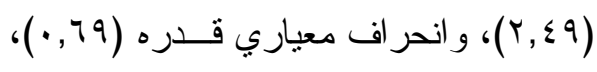

مما يشير إلى أن مستوى انفعــال الغــضب ولتب

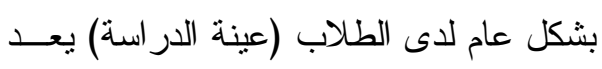

منوسطاً.

كما أظهرت النتائج أن قيمة المتوسط

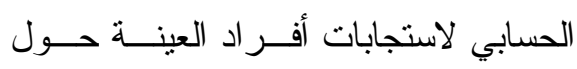

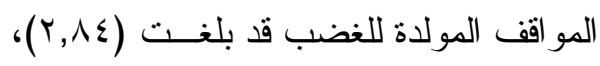
و انحر اف معياري قدره ( • 9 , ·)، وبالتــالي

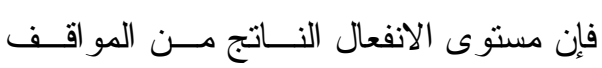

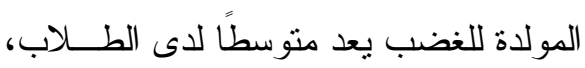

أسلوب على سلوكهم؛ سواء أكان في الجانب الإيجابي، أو السلبي.

كما أثنارت النتائج في الجــدول (v)

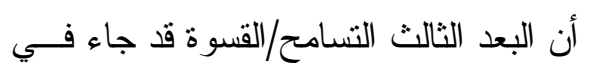

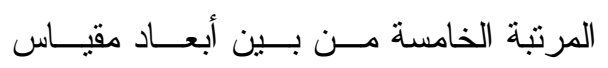

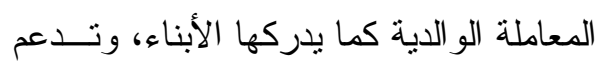

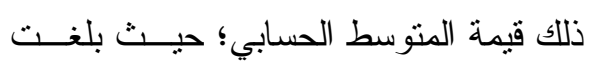

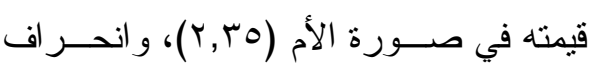

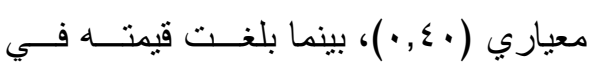

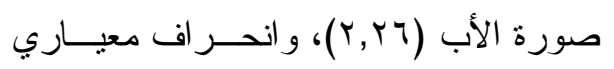
$\cdot(\cdot, \Sigma T)$

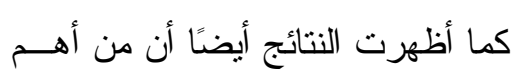
أساليب المعاملة الو الدية تأثثرًا على الأبنـــاء

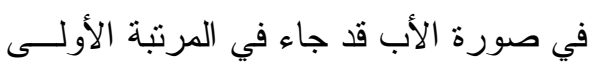

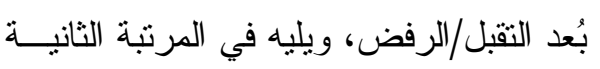
بُعد المساو اة/التقرقة، وفي المرتبة الثالثة بُعد

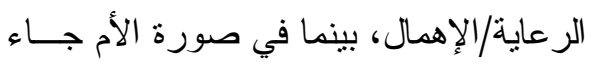
في المرتبة الأولى بعد التقبل/الرفض، ويليه

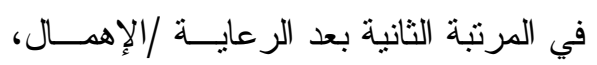

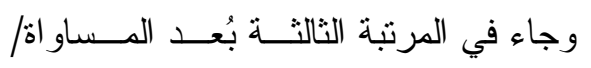

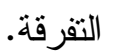
النتائج المتعلقة بالسؤال الثاني والذي ينص على: "ما مستوى انفعال الغضب لاى طلاب المرحلة الثانوية بمحافظة الليث؟". للإجابة عن هذا السؤ ال؛ قام الباحــث بحساب المتوسطات الحسابية و الانحر افــات لهابه 


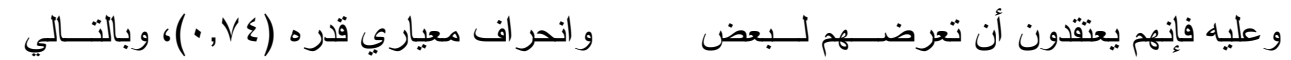

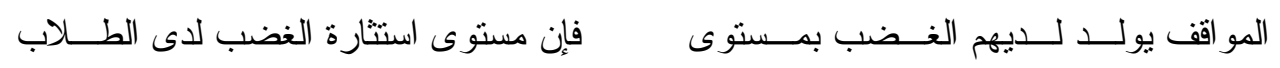

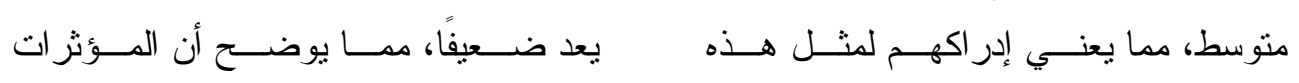

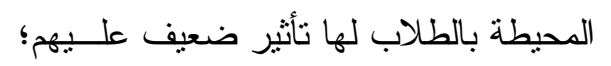
المو اقف. وقد يعزى ذلك إلى قلة العو امـلـل المــؤثرة داخل الأسرة على الأبناء.

وأبانت النتائج أن استجابات أفراد العينة المتعلقة بمسنوى استمرارية مثاعر النتائج المتعلقة بالسؤال الثالث والأي ينص الغضب لديهم قد نالت المرنبة الثانية من بين

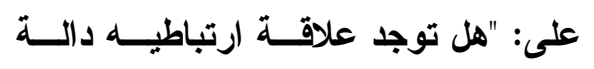
أبعاد مقياس الغضب، وتوضح ذلك قيمة

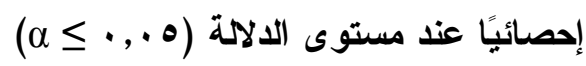

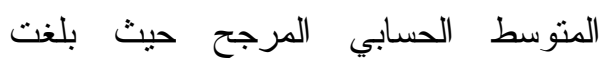

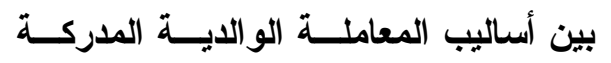
(Y, §V) وانفعال الغضب لاى طلاب المرحلة الثانوية

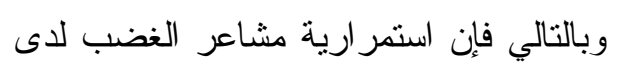

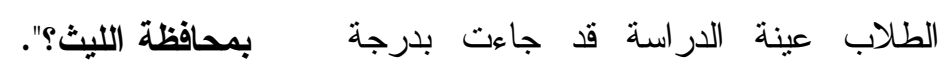
للإجابة عن هذا السؤال؛ قام الباحــث منوسطة، مما يعني عدم وجود عو امل مؤثرة

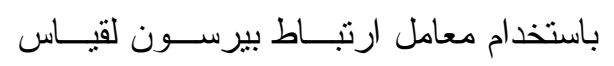

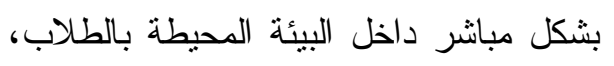
العلاقة بين درجات عينة الدر اسة في الأبعاد

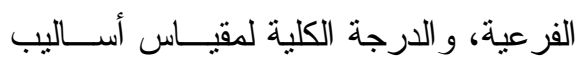
إذا كان مصدر هذا التأثثر محيط المدرسة،

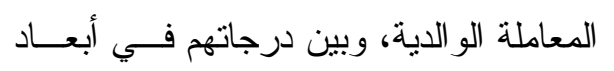

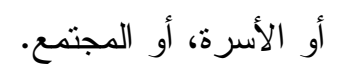

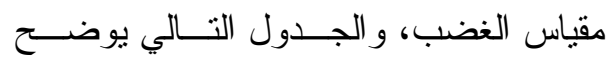
النتائج التي نم التوصل إليها: ولنيا:

كذللك أثنارت النتائج إلى أن مسستوى

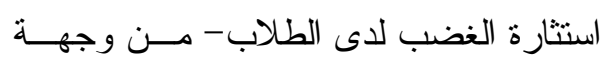
نظر هم- قد حازت على المرتبة الثالثة مسن

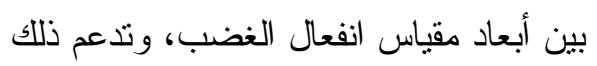

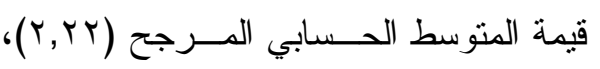




\section{العلاقة بين أساليب المعاملة الوالدية (صورة الأب) وانفعال الغضب:}

جدول (9)

معاملات ارتباط بيرسون لقياس العلاقة بين درجات أفراد عينة الدراسة في أبعاد مقياس

أساليب المعاملة الوالدية (صورة الأب) وبين درجاتهم في أبعاد مقياس الفضب

\begin{tabular}{|c|c|c|c|c|c|}
\hline لمقياس الغضب الكلية & استمرارية مشاعر & المواقف المولدة & استثارة الغضب & أبعاد الغضب & \\
\hline$* * \cdot, \backslash \wedge r-$ & $* * *, \backslash \wedge \wedge \wedge-$ & $* * \cdot, 1 \leq \leqslant 0-$ & $* *, Y Y \cdot 1-$ & معامل الارتباط & \multirow{2}{*}{ التقبل/ الرفض } \\
\hline عكسية (سالبة) & عكسية (سالبة) & عكسية (سالبة) & عكسية (سالبة) & وصف العلاقة & \\
\hline .,.r.o- & $\cdot, .010-$ & $\cdot, \cdot \leq \vee V$ & $\cdot, \cdot \wedge \wedge,-$ & معامل الارتباط & \multirow{2}{*}{ الرعاية/ الإهمال } \\
\hline شبه منعدمة & شبه منعدمة & شبه منعدمة & شبه منعدمة & وصف العلاقة & \\
\hline$* * \cdot$, หา91- & $* *, ., \Upsilon 9 \leq .-$ & $* *, \mid l r \lambda r-$ & $* * \cdot, r 101-$ & معامل الارتباط & \multirow{2}{*}{ التسامح/ القسوة } \\
\hline عكسية (سالبة) & عكسية (سالبة) & عكسية (سالبة) & عكسية (سالبة) & وصف العلاقة & \\
\hline 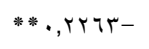 & $* * *, r \cdot \mid \Lambda-$ & $\cdot, \cdot 101-$ & $* *$, К & معامل الارنباط & \multirow{2}{*}{ المساواة/ التفرقة } \\
\hline عكسية (سالبة) & عكسية (سالبة) & شبه منعدمة & عكسية (سالبة) & وصف العلاقة & \\
\hline$* * \cdot 1991-$ & $* *$ * r Y $010-$ &., $.0 V \wedge-$ & $* *, Y 01 \leq-$ & معامل الارنباط & \multirow{2}{*}{ الديمقر اطية/ التسلط } \\
\hline عكسية (سالبة) & عكسية (سالبة) & شبه منعدمة & عكسية (سالبة) & وصف العلاقة & \\
\hline$* *$, * YVイA- & 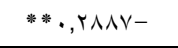 & $* \cdot, 11 r \cdot-$ & $* * \cdot$, น q & معامل الارتباط & \multirow{2}{*}{ ألأليب المعاملة الكلية لمقياس } \\
\hline عكسية (سالبة) & عكسية (سالبة) & عكسية (سالبة) & عكسية (سالبة) & وصف العلاقة & \\
\hline
\end{tabular}

* تشير إلى أن معامل الارتباط دال إحصائيًا عند مسنوى المعنوية (0. . •).

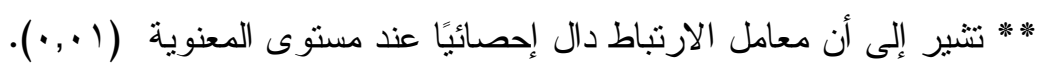

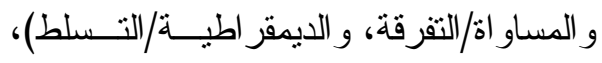
وبين بعد استثارة الغضب، مما يشير إلى أنه وله

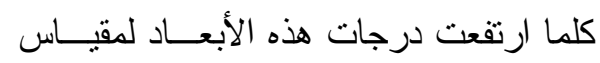

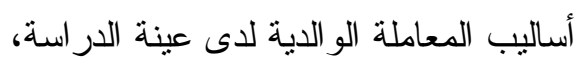

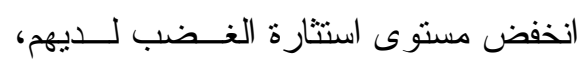
وبالتالي فإن ممارسة الأب لأساليب المعاملة

\section{العلاقة بين أساليب المعاملة الو الدية} (صورة الأب) وبعد استثارة الغضب: يتضح مــن الجــدول (9) أن هنــاك علاقات عكسية (سالبة) ذات دلالة إحصائية، بين أبعاد مقياس أساليب المعاملة الو الديــة:

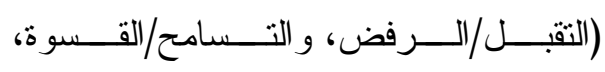


العلاقة بــين أســاليب المعاملـــة الوالديــة

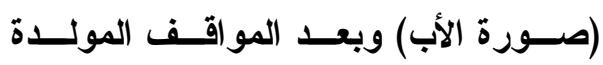
للغضب: يتضح مـن الجــدول (9) أن هنـــاك علاقات عكسية (سالبة) ذات دلالة إحصائية عند مستوى المعنوية (1 (., )، بـين أبعـاد

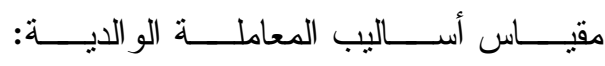

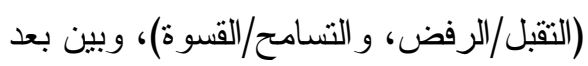

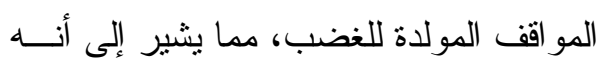

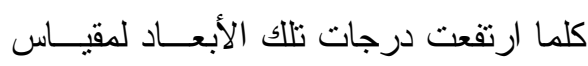
أساليب المعاملة الو الدية لدى عينة الدر اسة،

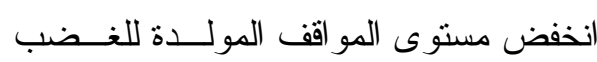

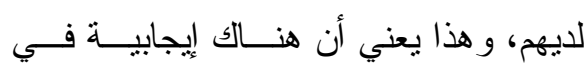

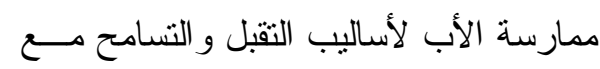

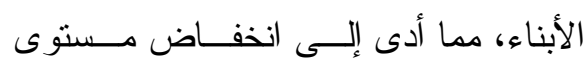
المو اقف المولدة للغضب لدى طلاب المرحلة

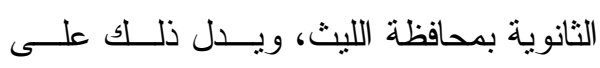
ممارسة الأب للجو انب الإيجابية مع الأبناء. كما يتضح من الجدول (9) أن العلاقة شبه منعدمة بين أبعاد مقياس أساليب المعاملة

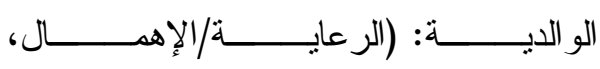

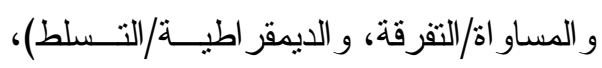

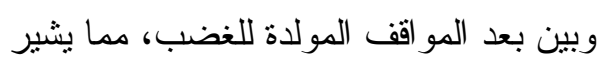

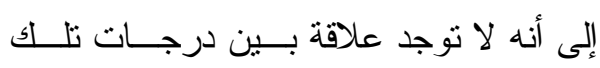

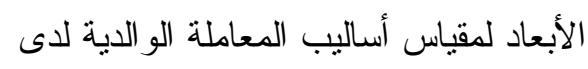
عينة الدر اسة، وبين مستوى المو اقف المولدة للغضب لديهم، وكانت تلاك النتائج غير دالــة
الإيجابية تسهم في انخفاض مـستوى إثــارة

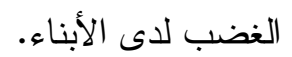

كما يتضح من الجدول (9) أن العلاقة شبه منعدمة بين بعد مقياس أساليب المعاملة

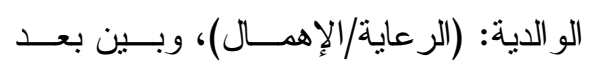

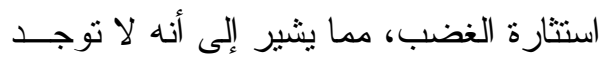

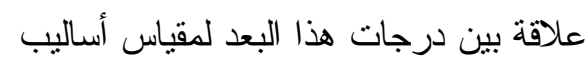

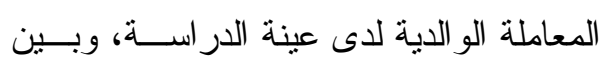

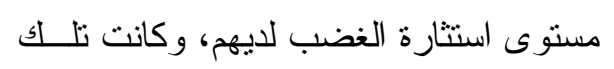

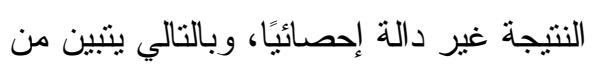

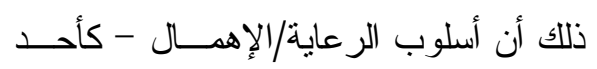

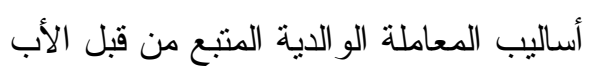

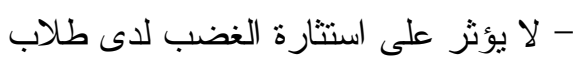
المرحلة الثانوية بمحافظة الليث. كذللك يتضح من الجدول (9) أن هناك علاقات ارتباطية عكسية (سالبة) بين الدرجة الكلية لمقياس أساليب المعاملة الو الدية، وبين بعد استثارة الغضب، مما يشير إلى أنه كلما

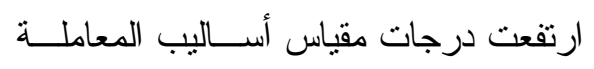
الو الدية لدى عينة الدر اسة، انخفض مستوى استثارة الغضب لديهم، وكانت تلألك العلاقــــة

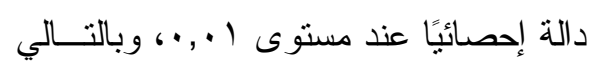

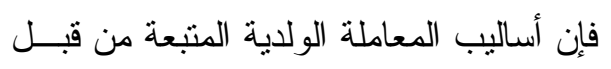
الأب تؤدي إلى انخفاض مـسـتوى اســنتارة

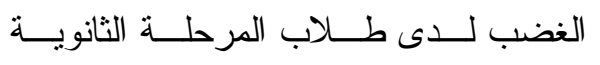
بمحافظة الليث. 
تأثنير معنوي في خفض استمر ارية مـشاعر

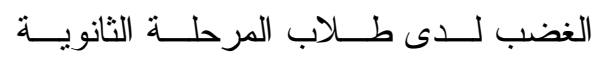
بمحافظة الليث.

كما يتـــح مــن الجــدول (Y I أن العلاقة شبه منعدمة بين بعد مقياس أســاليب

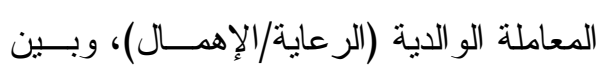
بعد استمر ارية مشاعر الغضب، مما يـشير لـشير إلى أنه لا نوجد علاقة بين درجات هذا البعد

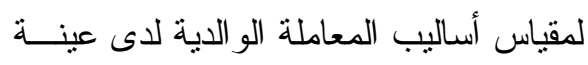

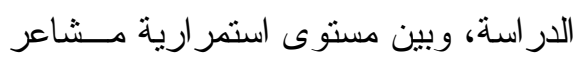
الغضب لديهم، وكانت نلاك النتيجة غير دالة إحصائيًا. كما أظهرت النتائج بالجــدول (9) أن

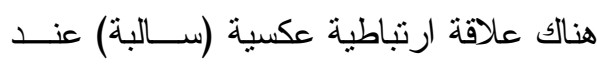
مستوى المعنوية (1 +., ·)، بين الدرجة الكلية

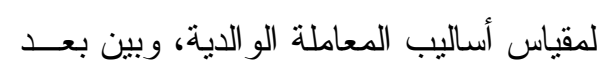

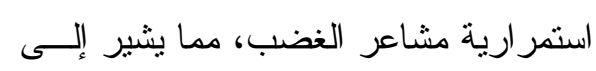

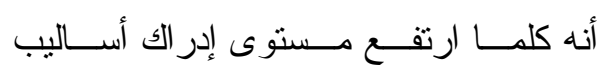

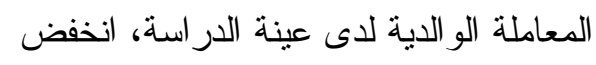

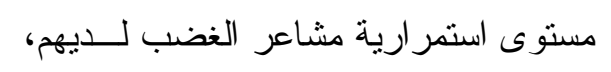
وبالتالي فإن لأساليب المعاملة الو الدية أثــرًا

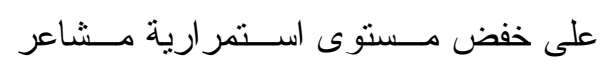

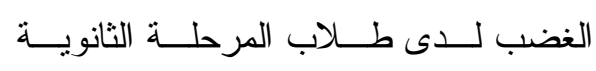
بمحافظة الليث.
إحصائيًا، وبالتالي فإنه لا يوجد أثز لأساليب

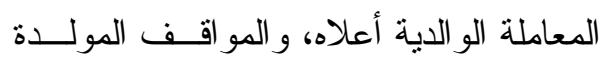
للغضب لاى طلاب المرحلة الثانوية. كما كثفت النتائج في الجدول (9) أن

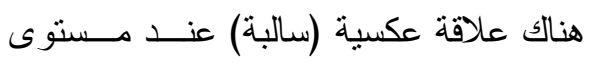
المعنوية (0. . •)، بين الدرجة الكلية لمقياس

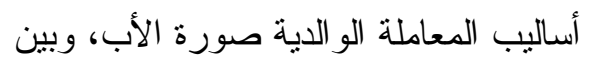

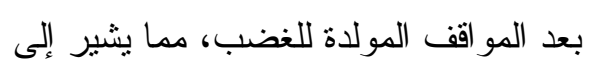

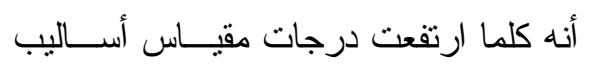

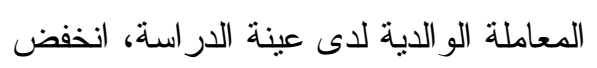
مستوى المو اقف المولدة للغضب لديهم. العلاقة بـين أســاليب المعاملـــة الوالديــة

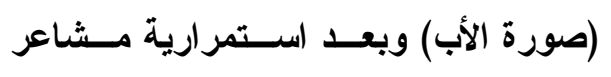
الغضب: كثنفت النتائج بالجدول (9) أن هنــاك علاقة ارتباطيــة عكــية (ســالبة) ودالـــة إحصائيًا عند مسنوى المعنوية (1 (., •)، بين

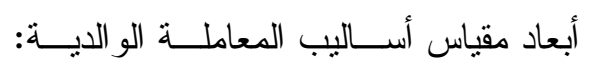

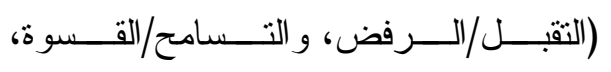

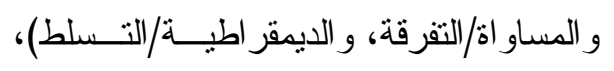
وبين بعد استمر ارية مشاعر الغضب، مدهـا

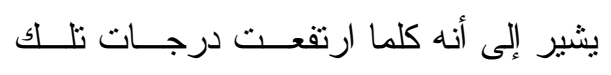
الأبعاد لمقياس أساليب المعاملة الو الدية لدى الدى

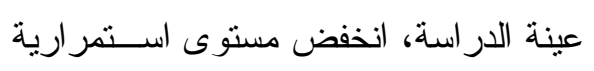
مشاعر الغضب لديهم، وبالتالي فإن ممارسة

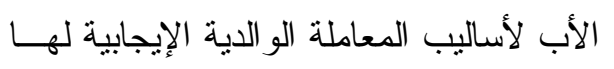


توجد علاقة بين درجات هذا البعد لمقيــاس

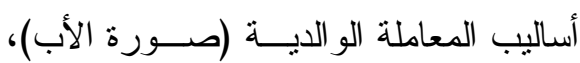

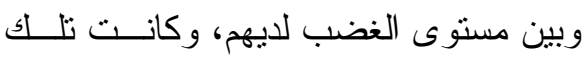
النتيجة غير دالة إحصائيًا، وبالنالي فإن عدم ولنئ

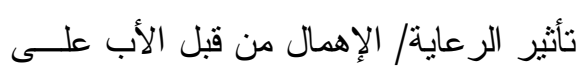

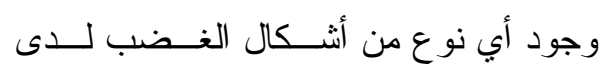
طلاب المرحلة الثانوية. كذلك يتبين من الجدول (9) أن هنالك علاقة ارتباطية عكسية (سالبة) ذات دلالــــة إحصائية عند مستوى المعنوية (1 ., •)، بين

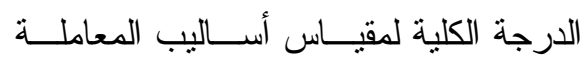

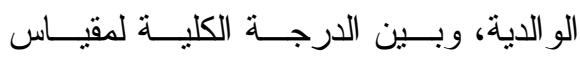

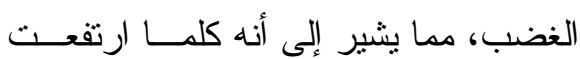

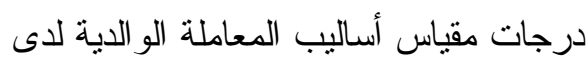

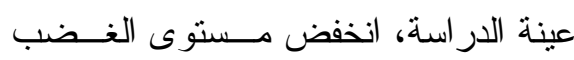
لديهم، وبالتالي فإن ممارسة أساليب المعاملة الو الدية بشكل إيجابي من قبـــل الأب تــؤدي

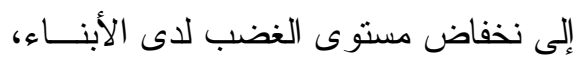

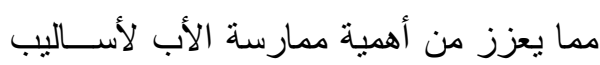

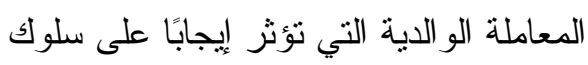
الأبناء الانفعالي.
العلاقة بــين أســاليب المعاملـــة الوالديــة

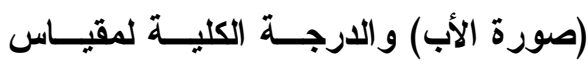
الغضب:

يتضح مــن الجـدول (9) أن هنــاك علاقة ارتباطيــة عكـسية (ســالبة) ودالـــة

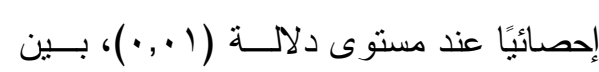

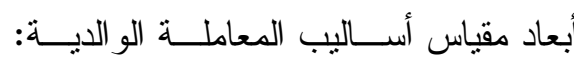

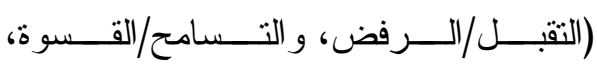

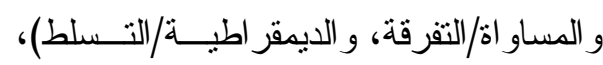

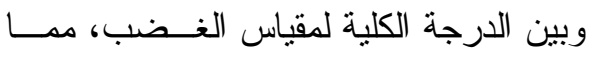

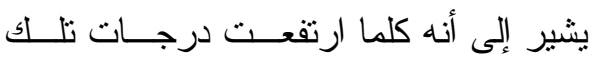
الأبعاد لمقياس أساليب المعاملة الو الدية لدى الدى لئل عينة الدر اسة، انخفض مـستوى الغــضب

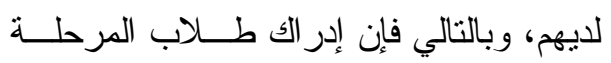

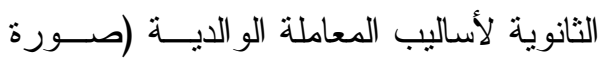

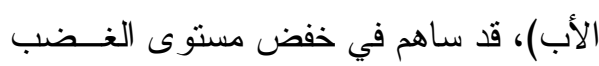
لديهم. كما يتضح من الجدول (9) أن العلاقة شبه منعدمة بين بعد مقياس أساليب المعاملة

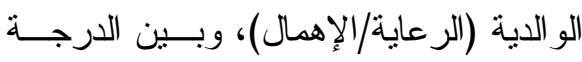

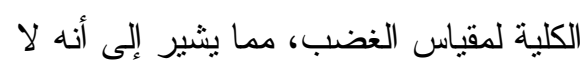


العلاقة بين أساليب المعاملة الوالاية (صورة الأم) وانفعال الغضب: جدول ( • 1) معاملات ارتباط بيرسون لقياس العلاقة بين درجات أفراد عينة الارسة في أبعاد

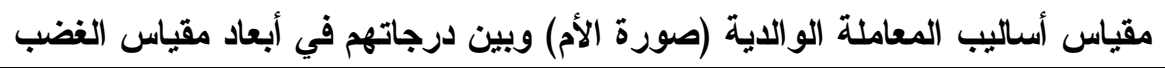

\begin{tabular}{|c|c|c|c|c|c|}
\hline لمقياس الغضة الكلية & استمر ارية مشاعر & للفضواقف المولدة & استثارة الغضب & أبعاد الغضب & \\
\hline$* *, 1190-$ & $*, 1 T 0 \leqslant-$ & *, Irr人- & $* *, r \cdot \mid r-$ & معامل الارتباط & \multirow{2}{*}{ التقبل/ الرفض } \\
\hline عكسية (سالبة) & عكسية (سالبة) & عكسية (سالبة) & عكسية (سالبة) & وصف العلاقة & \\
\hline$\cdot, \cdot r r \varepsilon-$ & $\cdot, \cdot 0 \cdot 1-$ & ש & $\cdot, \cdot \wedge 01-$ & معامل الارتباط & \multirow{2}{*}{ الرعاية/ الإهمال } \\
\hline شبه منعدمة & شبه منعدمة & شبه منعدمة & شبه منعدمة & وصف العلاقة & \\
\hline **, & $* *, r) \vee q-$ & $* *, 1071-$ & $* *, Y M V Y-$ & معامل الارتباط & \multirow{2}{*}{ التسامح/ القسوة } \\
\hline عكسية (سالبة) & عكسية (سالبة) & عكسية (سالبة) & عكسية (سالبة) & وصف العلاقة & \\
\hline$* * \cdot, 199 \wedge-$ & $* *, 19.1-$ & $\cdot, \cdot \leq 01-$ & $* *, Y V \cdot 1-$ & معامل الارنباط & \multirow{2}{*}{ المساواة/ التفرقة } \\
\hline عكسية (سالبة) & عكسية (سالبة) & شبه منعدمة & عكسية (سالبة) & وصف العلاقة & \\
\hline$* *, r \cdot r V-$ & **, r r & $\cdot, \cdot V \cdot r-$ & $* *,, r \leq \Lambda \leq-$ & معامل الارتباط & \multirow{2}{*}{ الايمقر اطية/ التسلط } \\
\hline عكسية (سالبة) & عكسية (سالبة) & شبه منعدمة & عكسية (سالبة) & وصف العلاقة & \\
\hline$* *$, roor- & $* *$, ror. - & $\cdot, .99 \wedge-$ & ***, • & معامل الارتباط & \multirow{2}{*}{ أساليب المعاملة الوالية الدية لمقياس } \\
\hline عكسية (سالبة) & عكسية (سالبة) & شبه منعدمة & عكسية (سالبة) & وصف العلاقة & \\
\hline
\end{tabular}

* نثبر إلى أن معامل الارنباط دال إحصائًا عند مسنوى المعنوية (0. , •). * *تير إلى أن معامل الارتباط دال إحصائيًا عند مستوى المعنوية (1 . , ). كلما ارتفعت درجات تلاك الأبعـاد لمقيــاس

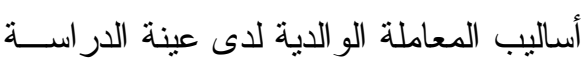
العلاقة بــين أســاليب المعاملـــة الو الايـــة (صورة الأم) وبعد استثارة الغضب:

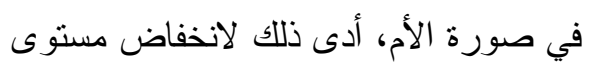
استثارة الغضب لديهم، وبالتالي فإن ممارسة لإنة

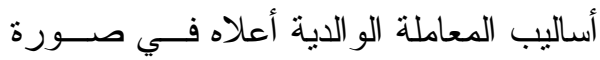
الأم بشكل إيجابي من جانب الأم، يسهم فــي خفض مستوى استثارة الغضب لدى الأبناء. كما يت ضـح مــن الجـدول (• (1) أن العلاقة شبه منعدمة بين بعد مقياس أســاليب يتضح من الجـدول (• (1) أن هنــاك

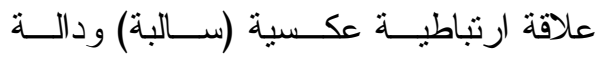
إحصائيًا عند مستوى المعنوية (1 ·, •))، بين أبعاد مقياس أســاليب المعاملـــة الو الديـــة:

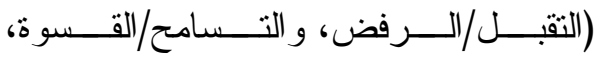

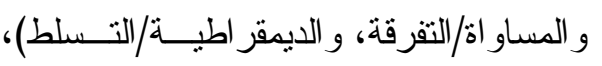
وبين بعد استثارة الغضب، مما يثير إلى أنه 
المو اقف المولدة للغضب، مما يشير إلى أنـــه

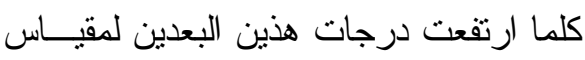
أساليب المعاملة الو الدية لدى عينة الدراسة،

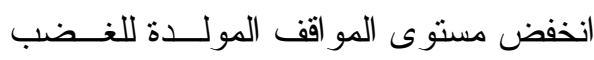

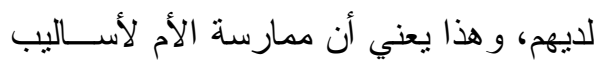

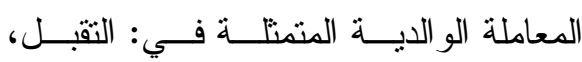

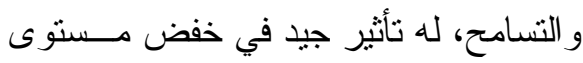
المو اقف المولدة للغضب لدى طلاب المرحلة الثانوية بمحافظة اللبث.

كما يتـــح مسـن الجــدول (• (1) أن العلاقة شبه منعدمة بين أبعاد مقياس أساليب

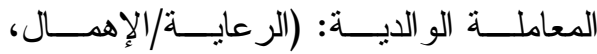

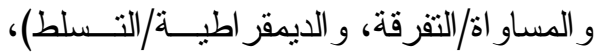
وبين بعد المو اقف المولدة للغضب، مما يثير

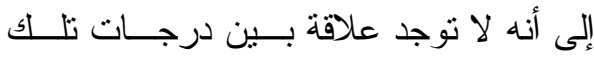
الأبعاد لمقياس أساليب المعاملة الو الدية لدى لإل عينة الدر اسة، وبين مستوى المو اقف المولدة للغضب لديهم، وكانت تللك النتائج غير دالـــة إحصائيًا، وقد يعزى ذللك إلى أن الأم دائمـــا

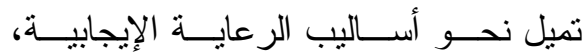

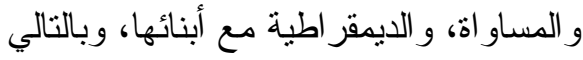
لا يؤدي منل هذا التعامل في أساليب المعاملة

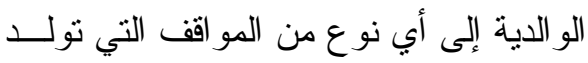

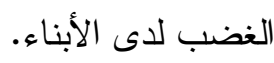

كذلك كثفت النتائج في الجدول (· ( ) أن العلاقة شبه منعدمة بين الدرجـــة الكليــة

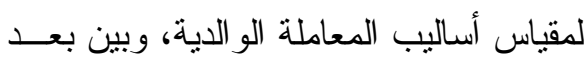

المعاملة الو الدية (الر عاية/الإهـــال)، وبــين

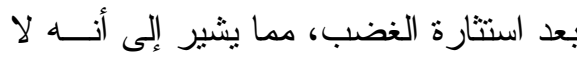

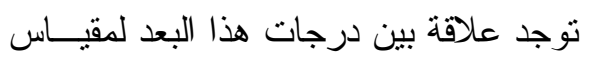
أساليب المعاملة الو الدية لدى عينة الدر اسة، وبين مستوى استثارة الغضب لايهه، وكانت تلاك النتيجة غير دالة إحصائيًا. كذلك يتضح مــن الجـدول (• (1) أن

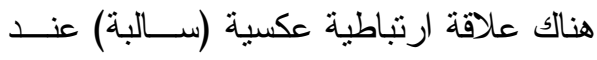
مستوى المعنوية (1 +., ) بين الدرجة الكلية

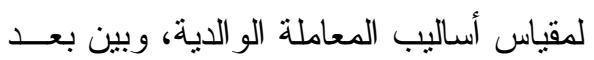

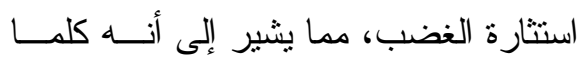

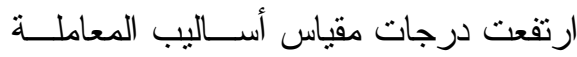
الو الدية لاى عينة الدر اسة، انخفض مستوى استتارة الغضب لديهم، وبالتالي فإن أســاليب

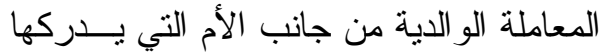

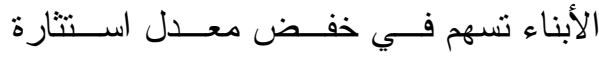
الغضب لايهم، مما يبــين أن ممارســـة الأم لأساليب المعاملة الإيجابية دائمًا ما يكون له له لهابل أثز إيجابي على خفضض مـسـتوى اســتنارة

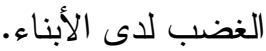

العلاقة بــين أســـاليب المعاملـــة الوالايـــة (صورة الأم) وبعد المواقف المولدة للفضب: يتضح من الجــدول (· (1) أن هنــالك علاقة ارتباطية عكسية (سالبة) وذات دلالــــة إحصائية عند مستوى المعنوية (0. , •)، بين أبعاد مقياس أســاليب المعاملـــة الو الديـــة: (التقبل/الرفض، و التسامح/القسوة)، وبين بعد التصاد 


$$
\begin{aligned}
& \text { سلوك الأبناء نحو تجنب استمر ارية مسشاعر } \\
& \text { الغضب لديهم. } \\
& \text { كما أظهرت النتائج بالجدول ( • () أن } \\
& \text { العلاقة شبه منعدمة بين بعد مقياس أســاليب }
\end{aligned}
$$

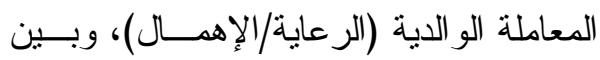

$$
\begin{aligned}
& \text { بعد استمر ارية مشاعر الغضب، مما يـشير لـشير } \\
& \text { إلى أنه لا نوجد علاقة بين درجات هذا البعد }
\end{aligned}
$$

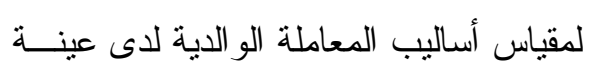

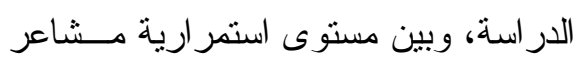

$$
\begin{aligned}
& \text { الغضب لديهم، وكانت تلاك النتيجة غير دالة } \\
& \text { إحصائيًا. } \\
& \text { كذلك كثفت النتائج بالجدول ( • () أن }
\end{aligned}
$$

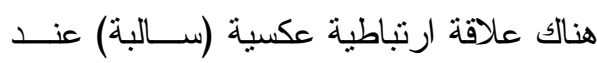

$$
\begin{aligned}
& \text { مسنوى المعنوية (1 +, •))، بين الدرجة الكلية }
\end{aligned}
$$

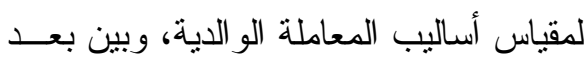

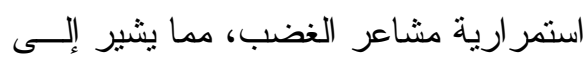

$$
\begin{aligned}
& \text { أن ارتفاع درجات مقياس أساليب المعاملــــة }
\end{aligned}
$$

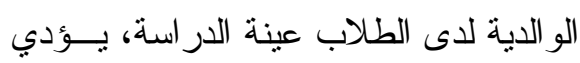

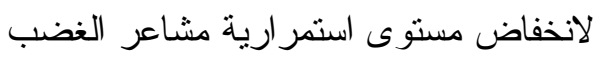

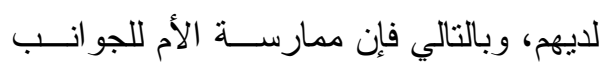

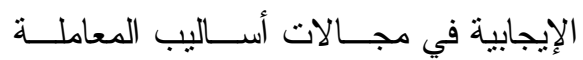

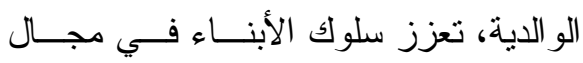

$$
\begin{aligned}
& \text { مشاعر الغضب، وهذا يبين مدى أهمية دور }
\end{aligned}
$$

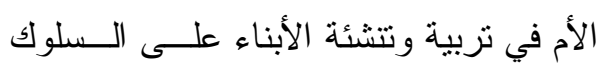

$$
\begin{aligned}
& \text { القويم. } \\
& \text { المو اقف المولدة للغضب، مما يشير إلى أنـــهـ } \\
& \text { لا نوجد علاقة بين درجات مقياس أســاليب لئل }
\end{aligned}
$$

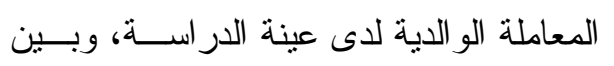

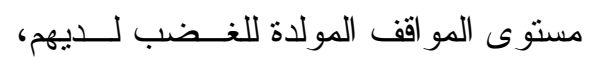

$$
\begin{aligned}
& \text { وكانت تلكك النتيجة غيــر دالـــة إحــصـئيًًا، } \\
& \text { وبالتالي فإن أساليب المعاملة الو الديــة مــن فئن }
\end{aligned}
$$

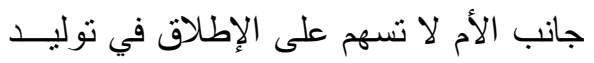

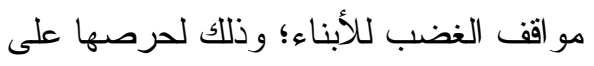

$$
\begin{aligned}
& \text { أن تكون علاقتها دائمًا متميزة مع الأبناء. } \\
& \text { العلاقة بــين أســاليب المعاملـــة الوالديــة }
\end{aligned}
$$

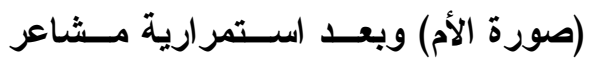

$$
\begin{aligned}
& \text { يتضح من الجـدول (• (1) أن هنــالك } \\
& \text { علاقة ارتباطية عكسية (سالبة) دالة إحصائيًا } \\
& \text { بين أبعاد مقياس أساليب المعاملة الو الديــة: }
\end{aligned}
$$

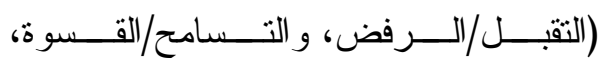

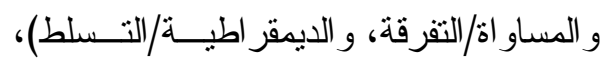

$$
\begin{aligned}
& \text { وبين بعد استمر ارية مشاعر الغضب، مهـــا }
\end{aligned}
$$

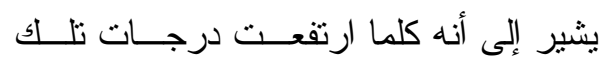

$$
\begin{aligned}
& \text { الأبعاد لمقياس أساليب المعاملة الو الدية لدى لـى لئه } \\
& \text { عينة الدر اسة، انخفض مستوى اســتمر ارية } \\
& \text { مشاعر الغضب لديهم، حيث كانــــ الدالالـــة } \\
& \text { الإحصائية تساوي (0. . • ) فأقل، وبالتـالي لـاني }
\end{aligned}
$$

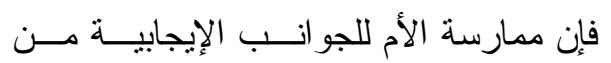

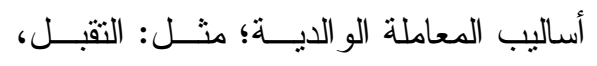

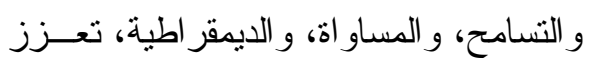


أن يؤدي إلى إحداث أي نـــوع مــن أنـــواع الغضب لايهم.

كذللك يتضح مــن الجـدول (• (1) أن

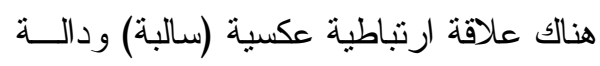

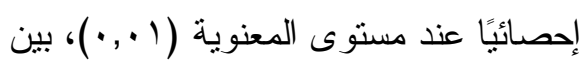

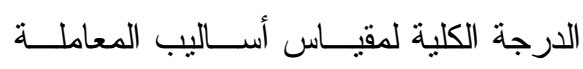

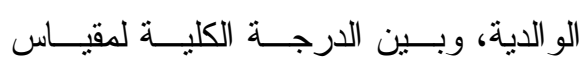

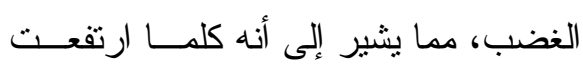

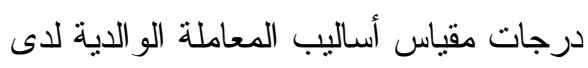

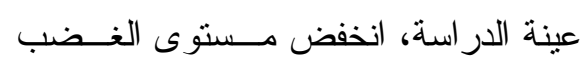

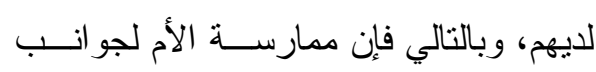

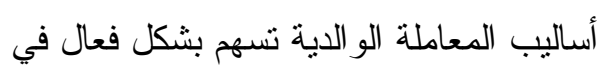

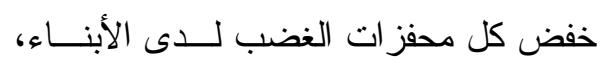
و هذا ينطبق مع ما خصها به الله - ســبحانه وتعالى - من عطف، وحنان، تجاه الأبناء.

توصيات الدراسة ومقتزحاتها:

أولاً: التوصيات: بناء على نتائج الدر اسة فإن الباحث يوصي بما يلي: البواء

ا - توعية الآباء و الأمهــات بالأســاليب

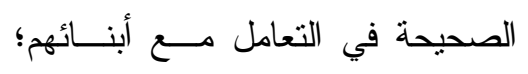

و هي: (الرعاية، و التقبل، و التـسامح،

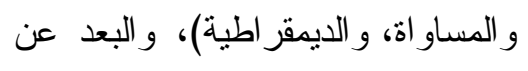

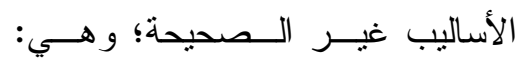

(الــــرفض، و الإهـــــال، و القــــوة

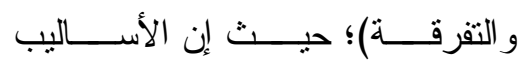

الصحيحة لها القدرة على التأثنر فـي التي
العلاقة بـين أســاليب المعاملــة الو الديــة

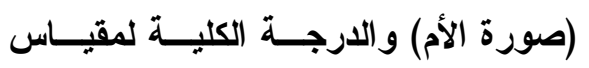
الغضب: كثف النتائج في الجدول (• (1) عـن

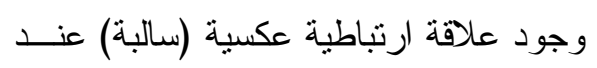

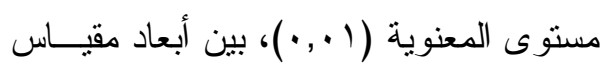

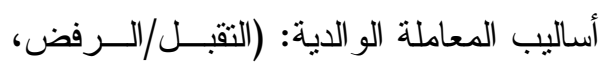

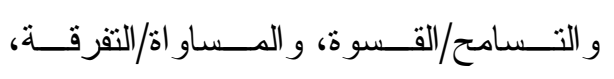

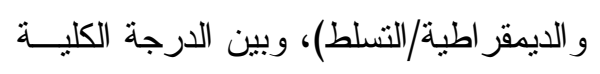

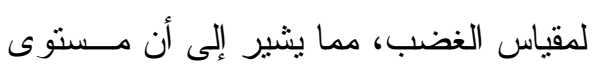
إدر الك الطلاب لأبعاد مقياس أساليب المعاملة

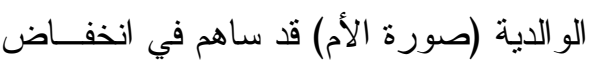
مستوى الغضب لديهم بشكل عام، و هذا يبين

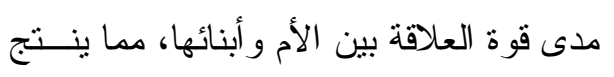

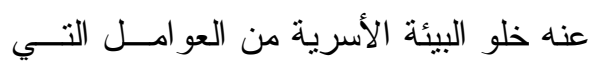

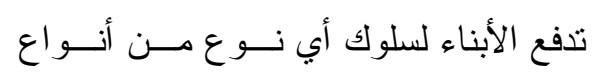
الغضب. كما بينت النتائج في الجدول (• (1) أن العلاقة شبه منعدمة بين بعد مقياس أســاليب

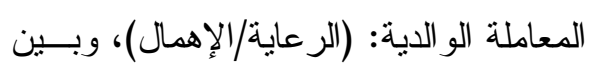
الدرجة الكلية لمقياس الغضب، مما يثير إلى لى النى

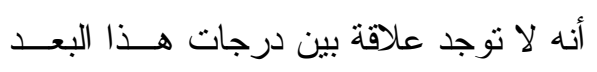

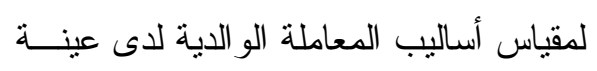
الدر اسة، وبين مستوى الغضب لدى الطلاب

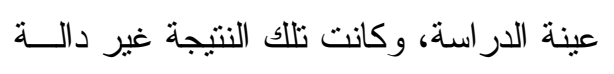
إحصائيًا، و هذا يبين أن ممارسة الأم لرعاية

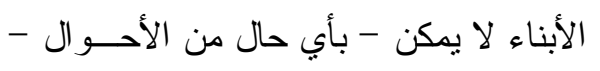




$$
\begin{aligned}
& \text { r- دراسة للكثف عن مسستوى انفعسال } \\
& \text { الغضب لدى طلاب المر احل الدراسية }
\end{aligned}
$$

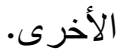

$$
\begin{aligned}
& \text { r- دراسة للكثف عن أسباب انخفــاض } \\
& \text { مستوى الغضب لدى طلاب المرحلــــة } \\
& \text { الثانوية بتعليم الليث. } \\
& \text { ـ - در اسة للكثف عن العلاقة بين أساليب }
\end{aligned}
$$

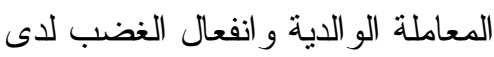

$$
\begin{aligned}
& \text { الأبناء من وجهة نظر الو الدين. }
\end{aligned}
$$

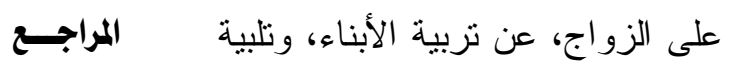

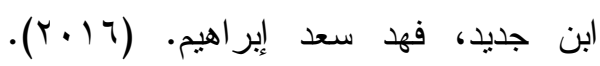

$$
\begin{aligned}
& \text { الغضب (حالة-سمة) وعلاقته بتأكيا } \\
& \text { الذات للى طلاب الثانوية العامة } \\
& \text { (رسالة ماجستير منشورة).كلية العلوم } \\
& \text { الاجتماعية والإدارية- جامعة نايف } \\
& \text { العربية للعلوم الأمنية. } \\
& \text { أحمد، فرحات. (Y (Y (Y). أساليب الدعاملة } \\
& \text { الوالدية (التقبل - الرفض) كما بيركها } \\
& \text { الأبناء وعلاقتها بالسلوك التوكيدي } \\
& \text { (رسالة ماجستير غير منشورة). } \\
& \text { جامعة تيزي وزو - الجزائر • } \\
& \text { البخاري، أبو عبد الله محمد بن إسماعيل. }
\end{aligned}
$$

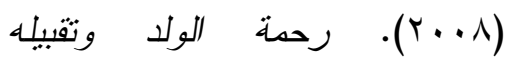

$$
\begin{aligned}
& \text { ومعانقته . بكير : دار السلام. لمان. } \\
& \text { جبريل، جلال مــن الله (1) (1) أســاليب } \\
& \text { التتــشئة الاجتماعيــة فـــي الأســرة }
\end{aligned}
$$

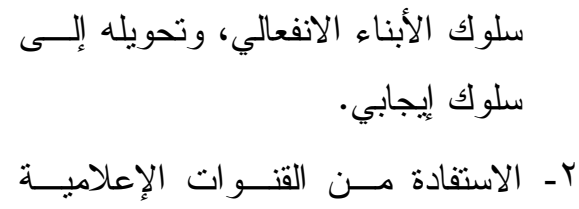

$$
\begin{aligned}
& \text { للجهات المسؤولة، في نـشـر رســائل }
\end{aligned}
$$

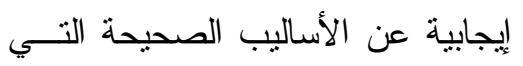

$$
\begin{aligned}
& \text { يتعامل بها الآباء مع الأبناء. } \\
& \text { r- تتفيذ بر امج تدريبية تأهيلية متخصصة }
\end{aligned}
$$

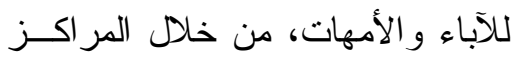

$$
\begin{aligned}
& \text { المجتمعية، وبر امج خاصـــة للمقبلــين } \\
& \text { احتياجاتهم؛ الجسمية، و النفسية. } \\
& \text { ع - الاستفادة من أئعة المساجد في نوعية }
\end{aligned}
$$

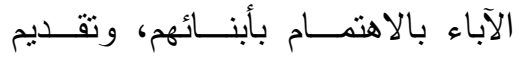

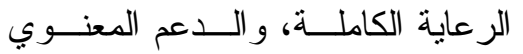

$$
\begin{aligned}
& \text { بمختلف أشكاله. } \\
& \text { هـ تثقيف طلاب المرحلة الثانوية - مـن }
\end{aligned}
$$

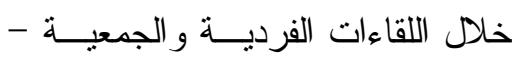

$$
\begin{aligned}
& \text { بأهمية فتزة المر اهقة، وما بــصاحبها } \\
& \text { من تغير ات جسمية، ونفسية. } \\
& \text { ثانيًا: مقترحات الدراسة: يقترح الباحث إجر اء }
\end{aligned}
$$

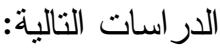

$$
\begin{aligned}
& \text { 1 - دراسة للكثف عن أساليب المعاملـــة }
\end{aligned}
$$

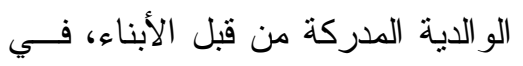

$$
\begin{aligned}
& \text { المر احل الدر اسية الأخرى (الابتدائية- } \\
& \text { المتوسطة- الجامعة). }
\end{aligned}
$$




$$
\begin{aligned}
& \text { بمحافظة القنفةة (رسالة ماجسنير غير } \\
& \text { وعلاقتها بتو افق الأبنــاء مـــع قـيم } \\
& \text { منشورة).كلية التزبية- جامعة الباحة. }
\end{aligned}
$$

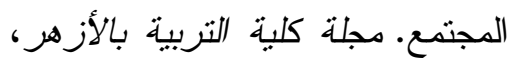

$$
\begin{aligned}
& \text { الز هـــار ، نجـــلاء الــسيد؛ وشــكر، فــاتن } \\
& .9 V-V r_{6}(r) \\
& \text { محمد.(11 + (r). العلاقة بين أســاليب } \\
& \text { التتشئة الاجتماعية و الذكاء الانفعـالي }
\end{aligned}
$$

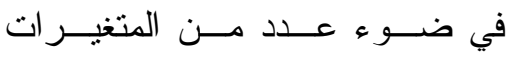

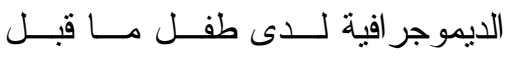

$$
\begin{aligned}
& \text { المدرسة. دراسات عربية في التربيــة }
\end{aligned}
$$

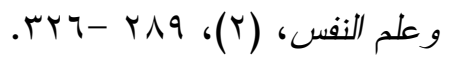

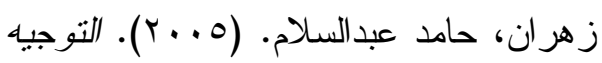

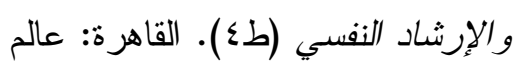

$$
\begin{aligned}
& \text { الكتب. } \\
& \text { السقاف، منال محمد.(^ . . r). الثقة بالنفس } \\
& \text { وانفعال الغضب لدى عينة من طلاب } \\
& \text { وطالبات جامعة الملك عبدالعزيز } \\
& \text { بجدة وجامعة أم القرى بمكة المكرمة } \\
& \text { (رسالة ماجستير غير منشورة). كلية } \\
& \text { التربية- قسم علم النفس- جامعة أم } \\
& \text { القرى- مكة المكرمة- المملكة } \\
& \text { العربية السعودية. } \\
& \text { سليمان، سناء محمد. (· (ب). الغضب: }
\end{aligned}
$$

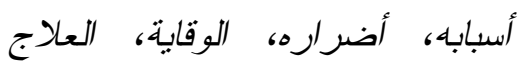

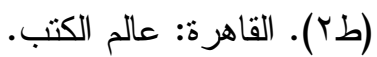

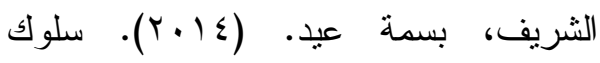

$$
\begin{aligned}
& \text { الغضب و علاقته بأساليب النتشئة } \\
& \text { الأسرية لاى طلبة المرحلة الثانوية } \\
& \text { جرجيس، أشواق سامي. (r (ب). الغضب } \\
& \text { وعلاقته ببعض ســمات الثخــصية. } \\
& \text { مجلة دراسات عربية في التربية وعلم } \\
& \text { النفس، (T (Y)، IVV }
\end{aligned}
$$

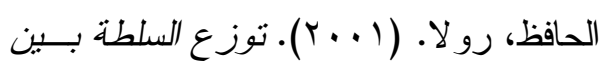

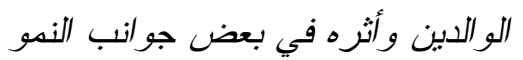

$$
\begin{aligned}
& \text { الاجتماعي للطفل، دراسة ميدانبة في } \\
& \text { رياض الأطفال بمدينة دمشق (رسالة } \\
& \text { ماجسنتر غير منشورة).كلية التربية- } \\
& \text { جامعة دمثق. }
\end{aligned}
$$

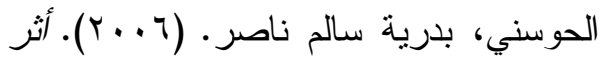

$$
\begin{aligned}
& \text { المعارسات الو الدية وبعض المتغيرات }
\end{aligned}
$$

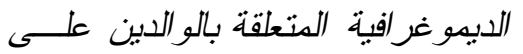

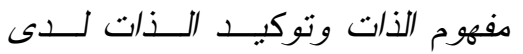

$$
\begin{aligned}
& \text { طالبات مرحلة ما بعد التعليم الأساسي ولئي } \\
& \text { بسلطنة عمان (رسالة ماجستير غيــر } \\
& \text { منشورة). الجامعة الأردنية. }
\end{aligned}
$$

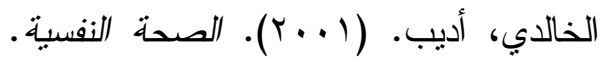

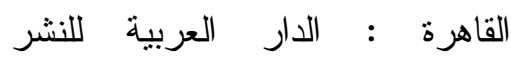

$$
\begin{aligned}
& \text { و التوزيع. - مان. } \\
& \text { الزبيدي، إبر اهيم حسـن.(10 + ب). أندـاط } \\
& \text { الهعاملة الو الدية وعلاقتها بالــصلابة الهابة } \\
& \text { النفسية لدى طلاب المرحلة الثانويــة }
\end{aligned}
$$




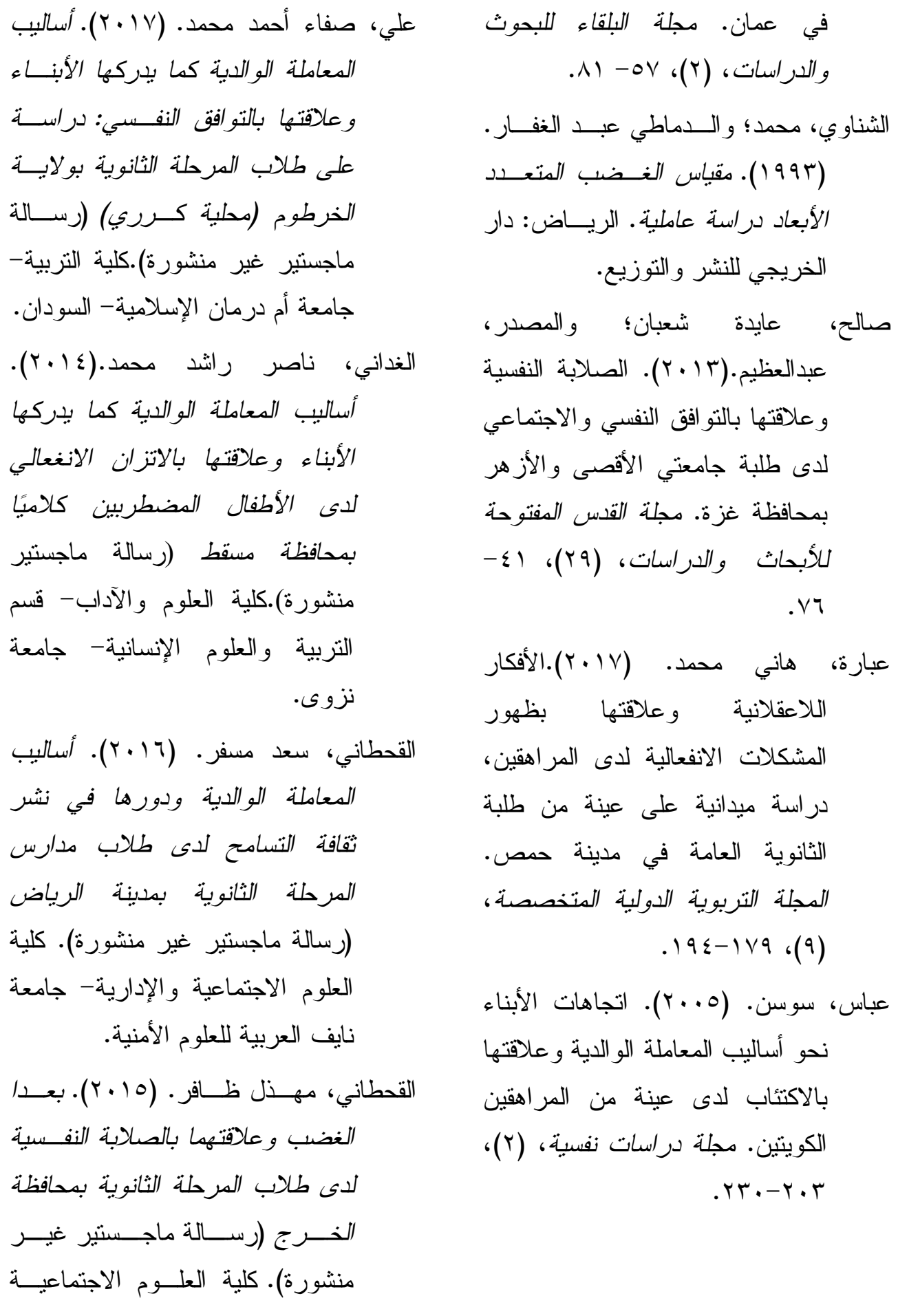


يحياوي، حسينة.(r + (Y). علاقة الغـضب

بظهـــور الــسلوك العـــدو اني لــدى

المر اهقين: در اسـة ميدانية بثانويــات

ولاية تيــزي وزو. مجلــة العلـــوم

الإنسانية و الاجتماعية، (Y) (I)،

$.1 Y$.

Averill, J.R. (1982) Anger and Agression: An Ess-ay on Emotion. New York 317, Springer-Verlag.

Lopez M., Becerra L, Garcia I.\& Gutierrez C. (2008). " Prevention of Child-teenage violence, Parenting Styles as Protection Factors", International Journal of Psychology \& psychological Therapy, Vol. (8), (1), pp. 73-84.

Tam, C., Chong, A., Kadirvelu, A., \& Khoo, Y. (2012). Paren ng Styles and Self- Efficacy of Adolescents: Malaysian Scenario. Global Journal of heman social Scienece, 12(14): 249- 260.

$$
\begin{aligned}
& \text { و الإدارية- جامعــة نــايف العربيــة }
\end{aligned}
$$

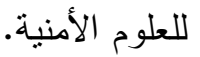

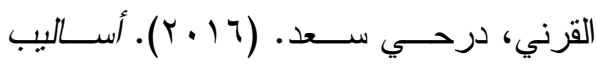

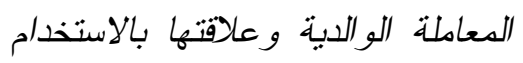

$$
\begin{aligned}
& \text { المفرط للإنترنت لاعى طلاب المرطلة } \\
& \text { الثانويــة (رســالة ماجسـتير غيــر } \\
& \text { الحامد للنشر و التوزيع. }
\end{aligned}
$$

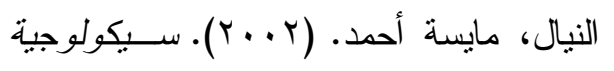

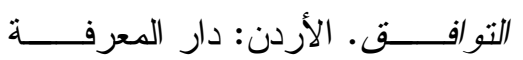

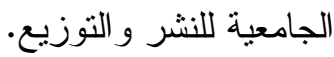

